\title{
IGF system in sarcomas: a crucial pathway with many unknowns to exploit for therapy
}

\author{
Caterina Mancarella and Katia Scotlandi \\ Experimental Oncology Lab, CRS Development of Biomolecular Therapies, Orthopaedic Rizzoli Institute, Bologna, Italy \\ Correspondence should be addressed to K Scotlandi: katia.scotlandi@ior.it \\ This paper forms part of a special section on 40 Years of IGF1. The guest editors for this section were Derek LeRoith and Emily Gallagher.
}

\begin{abstract}
The insulin-like growth factor (IGF) system has gained substantial interest due to its involvement in regulating cell proliferation, differentiation and survival during anoikis and after conventional and targeted therapies. However, results from clinical trials have been largely disappointing, with only a few but notable exceptions, such as trials targeting sarcomas, especially Ewing sarcoma. This review highlights key studies focusing on IGF signaling in sarcomas, specifically studies underscoring the properties that make this system an attractive therapeutic target and identifies new relationships that may be exploited. This review discusses the potential roles of IGF2 mRNA-binding proteins (IGF2BPs), discoidin domain receptors (DDRs) and metalloproteinase pregnancy-associated plasma protein-A (PAPP-A) in regulating the IGF system. Deeper investigation of these novel regulators of the IGF system may help us to further elucidate the spatial and temporal control of the IGF axis, as understanding the control of this axis is essential for future clinical studies.
\end{abstract}

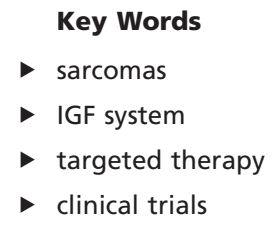

Journal of Molecular

Endocrinology (2018) 61, T45-T60

\section{Introduction}

The insulin-like growth factor (IGF) system is involved in many physiological and pathological processes throughout the life span. For example, longitudinal growth; metabolism; longevity and cell development and diseases, such as cancer, obesity, eating disorders and neurodegenerative illnesses, are influenced by the IGF pathway. Thus, IGF signaling must be carefully regulated not only in its magnitude but also in its timing and understanding the mechanisms behind the cell-/tissue-specific regulation of IGF system components is critical for efficiently targeting the system. However, much still needs to be understood. This review highlights key examples of the role of the IGF system in sarcoma pathogenesis and tumor progression and identifies new questions that need to be addressed to provide new fuel for the development of therapeutic strategies.

\section{Key points}

- Role of IGF system in sarcomas.

- Lessons learned from clinical studies on sarcomas vs carcinomas.

- Critical issues and novel perspectives.

\section{The IGF system}

The IGF system is a very complex system with multiple actors in play. Molecular details of the IGF system have been excellently reviewed by Samani and coworkers 
(Samani et al. 2007) and Taniguchi and coworkers (Taniguchi et al. 2006). It is beyond the scope of this manuscript to provide a detailed description of the complexity and interactions of this system at the molecular level. However, to inform the reader of the peculiarities of this signaling axis, the most relevant and critical issues are briefly described.

The IGF system is classically described as composed of three ligands (IGF1, IGF2 and insulin), their receptors (IGF1 receptor (IGF1R), mannose 6-phosphate/IGF2 receptor (M6P/IGF2R), insulin receptor (IR) and hybrid IR/ IGF1R), at least six IGF-binding proteins (IGFBP1-6), acid labile subunit (ALS) and binding protein proteases. Please refer to Fig. 1 for a schematic diagram of the system.

\section{Receptors, ligands and IGFBPs}

Insulin and IGFs activate intracellular signaling pathways by binding with high affinity to their cognate receptors (e.g. insulin $\rightarrow$ IR, IGFs $\rightarrow$ IGF1R) and with lower affinity to a noncognate receptor (e.g. insulin can also activate IGF1R and IGFs can activate IR). IGF2 also binds IGF2R, which is a mannose 6-phosphate scavenger receptor that does not transmit signals intracellularly. IR has two splice isoforms, IRA, which is highly expressed in fetal tissues and cancer, and IRB, which is mainly present in adult tissues (for a detailed review, please refer to Belfiore et al. 2009). While IRB is a specific receptor for insulin and thus primarily mediates metabolic effects, IRA binds IGF2 and IGF1 (at a lower affinity) and may induce biological effects in response to both IGFs with substantial crosstalk with the IGF1R mitogenic signaling pathway. IGF1R shares 70\% homology with IR. Because of the close homology between IR and IGF1R, hybrid receptors can be formed via an interaction between an insulin alpha-beta hemireceptor and an IGF1 alpha-beta hemireceptor in cells expressing both. Hybrid receptors appear to bind IGF1 and IGF2 with a high affinity similar to IGF1R. The interaction between the ligands (IGF1 and IGF2) and IGF1R, IR or the hybrid receptors results in trans-autophosphorylation of the intracellular portion of the receptors and the subsequent recruitment of downstream signaling adaptor proteins, IR substrate (IRS) 1-6 and Src homology 2 domain-containing transforming protein (Shc), to the cell membrane (for reviews see Butler et al. 1998, Samani \& Brodt 2001). The subsequent phosphorylation of these proteins induces the activation of phosphoinositide 3-kinase (PI3K) (Giorgetti et al. 1993) and mitogen-activated protein kinases (MAPK) pathways (Grey et al. 2003),

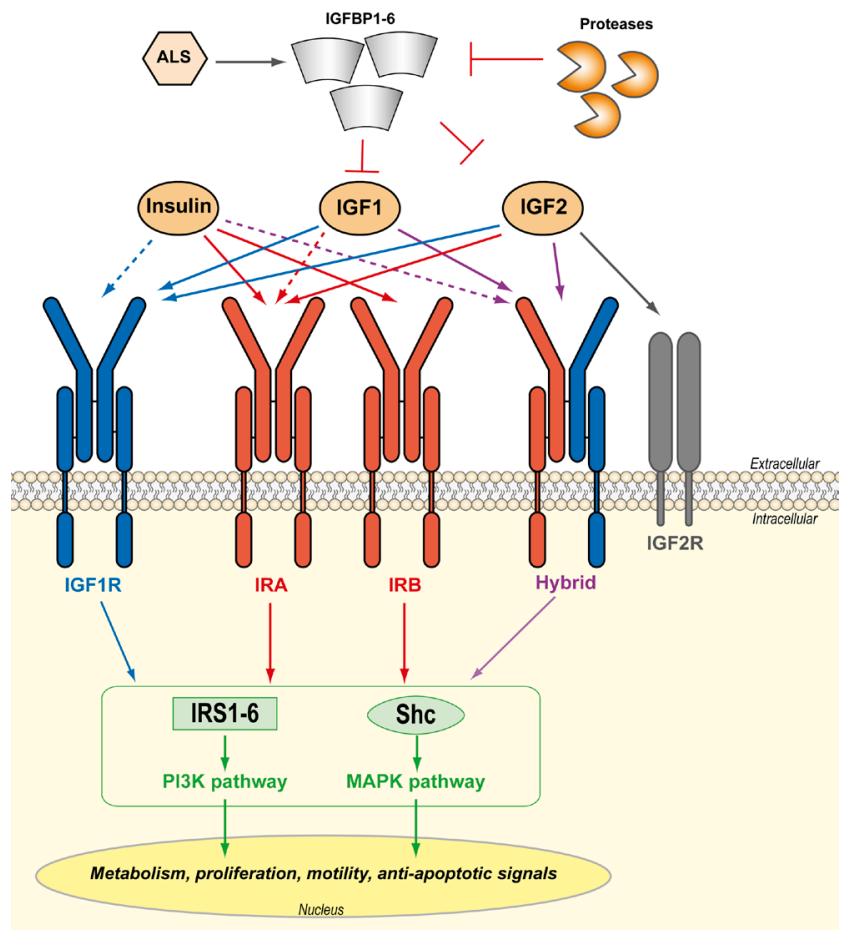

Figure 1

Schematic representation of the IGF system, interactions among its components and signal transduction. In the extracellular compartment, the ligands (IGF1, IGF2 and insulin) and the family of 6 IGFBPs, which are controlled by the activity of proteases and ALS, are depicted. Each ligand displays a specific binding affinity for the receptors: continuous arrows indicate high affinity, while dotted arrows indicate low affinity. IGF1R, IR isoforms (IRA and IRB), hybrid receptors and IGF2R are shown in the cell membrane. In the intracellular compartment, upon binding the ligand, the kinase domains of the receptors are activated and serve as docking sites for downstream substrates including IRS1-6 and Shc. These substrates initiate phosphorylation cascades through the PI3K or MAPK pathways, which transmit the signal to the nucleus. ALS, acid labile subunit; IGF, insulin-like growth factor; IGF1, insulin-like growth factor 1; IGF2, insulin-like growth factor 2; IGF1R, insulin-like growth factor 1 receptor; IGF2R, insulin-like growth factor 2 receptor; IGFBPs, insulin-like growth factor binding proteins; IR, insulin receptor; IRS, insulin receptor substrate; MAPK, mitogen-activated protein kinase; PI3K,

phosphoinositide 3-kinase; Shc, Src homology 2 domain-containing transforming protein.

resulting in the stimulation of cellular proliferation and cell motility and the inhibition of apoptosis. Although the IGF system receptors have many similarities, the biological response elicited by each IGF system receptor can vary depending on (1) the ligands involved, (2) the expression of a specific IR isoform and (3) the recruitment of certain docking proteins and intracellular mediators, and the dynamics and regulation involved are still not completely understood (Frasca et al. 2008).

These complex functional interconnections between receptors and ligands imply that whenever the effects of IGF1R, IR or both are studied, the prevalent types and 
expression levels of the ligand(s) in that specific cellular context should also be examined. When exploring IGF1R and IR signaling in cancer, considerable attention was given to abnormal signaling after the interactions between IGFs and their receptor/s. However, the mechanism by which IGFs and/or insulin in plasma are regulated prior to interacting with their receptor/s is as important as the intracellular signaling pathway. Many epidemiological studies reported that individuals with IGF1 levels at the upper end of the normal range have an increased risk of developing certain cancers, e.g. prostate, breast and colon cancers (Chan et al. 1998, Endogenous et al. 2010, Rinaldi et al. 2010). Conversely, individuals with Laron's syndrome, which is characterized by very low IGF1 levels, appear to be protected from the development of cancer (Shevah \& Laron 2007); moreover, reducing circulating IGF1 levels by caloric restriction decreases tumor growth (Brandhorst et al. 2015).

\section{Relevant checkpoints in regulating the IGF system}

The level of free IGFs is affected by the rate of IGF production, clearance and binding to IGFBPs. IGFs circulate in large part bound to one of the six IGFBPs, mainly IGFBP3 and IGFBP5, fractions of which further form ternary complexes with ALS. This results in an increase in IGFs half-life (Baxter 2000). The IGFBPs circulate in molar excess of IGFs and have ligand affinities at the same order of magnitude as the ligands have for the IGF1R (Clemmons 1998). Most IGFBPs compete with IGFs for binding to respective receptors and antagonize IGF function, while some (e.g., IGFBP2) appear to amplify IGF signaling (Grimberg \& Cohen 2000). Mohan and Baylink provided a detailed review on IGF-binding proteins that regulate the biological accessibility and activity of IGFs (Mohan \& Baylink 2002). In addition to IGF-dependent mechanisms of actions, IGFBPs bind non-IGF ligands in the extracellular space, cell membrane, cytoplasm and nucleus, thereby modulating cell proliferation, survival and migration in an IGF-independent manner (Granata et al. 2004, Han et al. 2011).

Alterations in IGF-mediated functions also involve modulating IGF2R, which lacks transketolase activity, does not transmit signals, and may serve as a scavenger receptor for IGF2. Loss-of-functional IGF2R, a condition largely observed in tumors, likely facilitates an enhanced interaction between IGF2 and IGF1R (Devi et al. 1999, Martin-Kleiner \& Gall Troselj 2010). In addition, alterations in phosphatase and tensin homologue (PTEN), which is a tumor suppressor and lipid phosphatase (Zhao et al.
2004), and altered expression of adaptor proteins IRSs (Chang et al. 2002) and Shc (Ursini-Siegel et al. 2008) are also involved in IGF signaling regulation.

Finally, recent discoveries on post-transcriptional and proteolytic regulation of IGF activity have provided novel insights into the intricate control of the IGF system.

To date, no reports have described mutations in any genes encoding IGFs, receptors or the six IGFBPs; however, a notable exception is osteosarcoma, where recurrent mutations in genes mediating IGF signaling via IGF1R (focal amplification of IGF1R and IGF1; frameshift indels in recessive cancer genes, IGF2R and IGFBP5) have been recently described in $7 \%$ of tumors (Behjati et al. 2017). More commonly, reports have described the expression of IGF system players, to a large extent, at the transcriptional and post-transcriptional levels with functions that can be influenced by genetic and epigenetic changes. Interestingly, mutations in metalloproteinase pregnancyassociated plasma protein-A2 (PAPP-A2), one of the proteases believed to increase the local bioavailability of IGFs by cleaving inhibitory IGFBPs (Conover 2012), were recently discovered in patients with growth failure (Dauber et al. 2016). The impact of these mutations in cancer, as well as the expression of stanniocalcin 1 and 2 (STC1 and STC2), which are potent proteinase inhibitors of PAPP-A (Jepsen et al. 2015, Kloverpris et al. 2015), have been poorly explored in relation to the IGF system; however, these alterations may significantly affect the role of PAPP-A in certain malignancies. Targeting the proteolytic activity of PAPP-A is relevant to preventing cancer growth and metastases (Becker et al. 2015), thus sustaining further investigations.

Beyond their canonical role in digesting extracellular matrix proteins, matrix metalloproteinases (MMPs) have a specific role in cleaving IGFBPs, thus leading to IGF liberation. In epithelial cells, IGFBP5 is cleaved by MMP7, which consequently releases IGF2 and promotes a proliferative cellular response (Hemers et al. 2005). In prostate cancer cells, MMP9 was described as having a proteolytic effect on IGFBP3 (Manes et al. 1999). In this perspective, targeting MMPs was postulated as a novel therapeutic strategy against cancer (Egeblad \& Werb 2002).

Another interesting regulator of the IGF system are the IGF2 mRNA-binding proteins, a family of mRNAbinding proteins (RBPs) consisting of three paralogs (IGF2BP1, 2 and 3) involved in RNA localization, translation and stability (Christiansen et al. 2009). These RBPs are oncofetal proteins that are highly expressed during both human and mouse embryogenesis. Although 
these RBPS may affect stability and translation of many transcripts, Nielsen and colleagues demonstrated that IGF2BPs specifically drive physiological regulation of IGF2 translation at both a temporal and spatial level during late mammalian development (Nielsen et al. 1999). With the notable exception of IGF2BP2, IGF2BP1 and IGF2BP3 are expressed at low levels in adult tissues and are re-expressed in malignancies. Of note, IGF2BP3 has been described as playing a specific role in regulating IGF2 and IGF1R mRNA expression that leads to increased IGF signaling in different tumor types (Hafner et al. 2010, Fawzy et al. 2016, Panebianco et al. 2017).

Moreover, previous studies described novel relevant interactions between IGF1R or IR and discoidin domain receptor 1 (DDR1). DDR1 belongs to a subfamily of membrane tyrosine kinase receptors, including five DDR1 isoforms and DDR2, and these DDRs bind to and are activated by different types of collagen (for a review, consider (Valiathan et al. 2012)). DDRs are characterized by an extracellular discoidin domain, a long juxtamembrane region and 13-15 tyrosine residues in their cytoplasmic domain that serve as binding sites for $\mathrm{SH} 2$ and phosphotyrosine-binding (PTB) domain-containing molecules for signal transduction. Interestingly, DDR1 constitutively associates with IGF1R, and this interaction is enhanced after IGF stimulation and leads to an increase in IGF1R expression levels as well as signaling and biological effects. Importantly, silencing DDR1 was found to decrease the IGF1R biological response after IGF stimulation, and the absence of IGF1R was reported to impair collagen-dependent DDR1 activation, thus further indicating the close crosstalk between the two molecules (Malaguarnera et al. 2015). Similarly, in response to insulin or IGF2, DDR1 co-localizes with IRA and influences its biological actions. Indeed, DDR1 knockdown inhibits IRA signaling, as well as IRA-elicited proliferation and migration after ligand stimulation. Importantly, DDR1 regulates IR expression levels through both transcriptional and post-transcriptional mechanisms (Morcavallo et al. 2011, Vella et al. 2017).

Please refer to Fig. 2 for a schematic representation of the IGF system and all relevant regulators controlling this axis.

Despite this level of complexity, IGF1R signaling has been the only focus of previous studies, and selective IGF1R inhibitors have been the first and, unfortunately, the only therapy to progress from bench to bedside. Considering these intricacies of the IGF system, it is now clear that the current understanding of this system is a gross oversimplification of the real interconnections that may alter IGF-mediated signals.

Historically, IGF1R was chosen as the therapeutic target because of the following: (i) the first evidence by Sell and colleagues demonstrated that IGF1R is quasiobligatory for cell transformation (Sell et al. 1993) and (ii) multiple preclinical studies demonstrated that downregulation or inhibition of IGF1R in malignant cells induces cell death, inhibits tumorigenesis and metastasis and increases chemosensitivity to conventional and targeted drugs.

It was therefore not surprising that targeting IGF1R became popular with pharmaceutical companies. Monoclonal antibodies and tyrosine kinase inhibitors were designed to specifically target IGF1R, and several phase I to III clinical trials were conducted. From these studies, we obtained some important indications: (1) anti-IGF1R drugs have modest toxic effects and (2) antiIGF1R drugs show limited effectiveness. Because of this disappointing evidence, the development of anti-IGF1R agents was largely abandoned. However, sarcoma studies found a few extraordinary results that deserve deeper analysis and follow-up investigations.

\section{IGF system in sarcomas}

The IGF system has been demonstrated to be clearly involved in the pathogenesis and progression of sarcomas that tend to occur in younger patients, such as osteosarcoma, Ewing sarcoma and rhabdomyosarcoma. Although there are no direct data describing a relationship between IGF levels and sarcoma risk, the peak incidence of primary bone sarcoma (osteosarcoma and Ewing sarcoma) correlates with increased levels of IGF ligands in puberty. Growth hormone (GH) and IGFs are important regulators of growth and development in normal bone and contribute to approximately $50 \%$ of basal bone cell proliferation (for reviews see Cannata et al. 2010, Al-Kharobi et al. 2014). IGFs also promote differentiation of myoblastic or osteoblastic tissues into muscle and bone (Schmid et al. 1983), and glucose uptake favors osteoblast differentiation by suppressing AMP-activated protein kinase (AMPK)-dependent proteasomal degradation of Runx2 (Wei et al.2015), a master determinant of osteoblast differentiation. Thus, it is conceivable that defects in molecules involved in IGF signaling may play a role in the formation of musculoskeletal tumors.

Previous studies described the expression of IGFs and IGF1R in tumor cells from primary high-grade osteosarcoma, which is an aggressive tumor derived from 


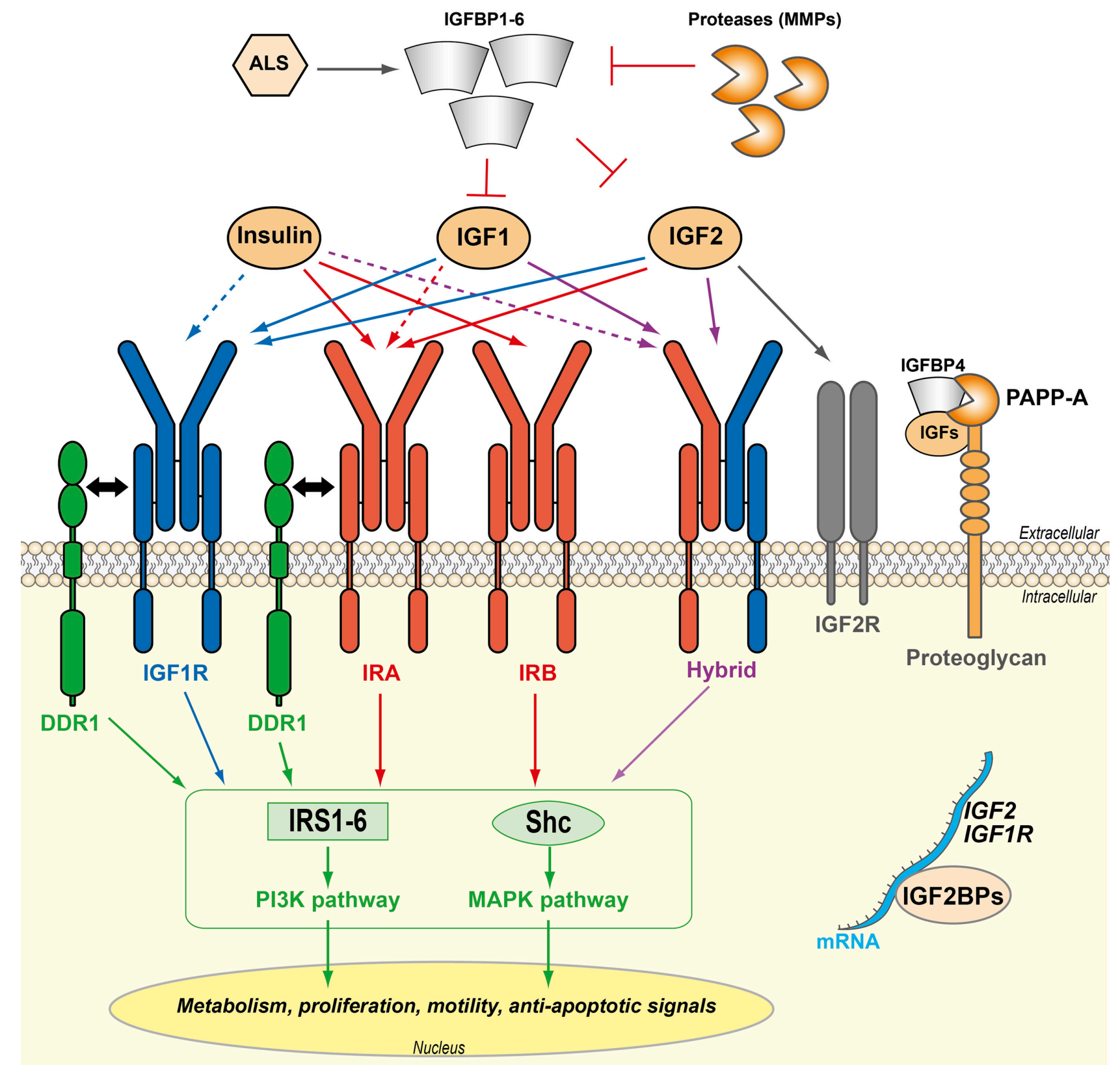

\section{Figure 2}

Schematic representation of the complexity surrounding the IGF system. Canonical components and interactions as well as novel regulators and binding partners of the IGF system are presented. The IGFBP family, ligands and their receptor-binding affinities are shown in the extracellular compartment: continuous arrows indicate high affinity, while dotted arrows indicate low affinity. As reported, IGFBP proteases include MMPs and PAPP-A. Specificity of PAPP-A for binding to the IGFBP4/IGF complex is shown. Alongside IRB, hybrid receptors and IGF2R, the direct interaction between DDR1 and IGF1R or IRA and the impact of these interactions on the PI3K and MAPK downstream pathways are shown in both the membrane and intracellular compartment. Cytoplasmic regulation of IGF2 and IGF1R mRNA by IGF2BPs is depicted. ALS, acid labile subunit; DDR1, discoidin domain receptor 1; IGF, insulin-like growth factor; IGF1, insulin-like growth factor 1; IGF2, insulin-like growth factor 2, IGF1R, insulin-like growth factor 1 receptor; IGF2BPs, insulin-like growth factor 2 mRNA-binding proteins; IGF2R, insulin-like growth factor 2 receptor; IGFBPs, insulin-like growth factor binding proteins; IR, insulin receptor; IRS, insulin receptor substrate; MAPK, mitogen-activated protein kinase; MMPs, matrix metalloproteinases; PI3K, phosphoinositide 3-kinase; Shc, Src homology 2 domain-containing transforming protein.

osteoblastic precursors and found that IGF and IGF1R expression levels are functionally related to malignant growth and invasion in several preclinical models
(Kappel et al. 1994, Benini et al. 1999, MacEwen et al. 2004, Duan et al. 2009, Kuijjer et al. 2013, Cao et al. 2014). Loss of IGFBPs and IGFBP-related proteins (IGFBP-rPs), 
which are generally believed to inhibit the effects of IGFs, has also been found in osteosarcoma but not normal bone cells (Yang et al. 2016). Of note, during normal osteoblastic terminal differentiation, the expression of IGFs progressively increased, while the expression of IGF1R progressively decreased (Viereck et al. 2007), suggesting that upregulation of the receptor, rather than the ligands, is the aberrant condition in osteosarcoma. Accordingly, using fluorescence in situ hybridization, Behjati and coworkers (Behjati et al. 2017) found highlevel amplification of $I G F 1 R$ in $14 \%$ of cases, while mutations in genes mediating signaling via IGF1R were found in $7 \%$ of patients. Polymorphisms of IGF2R are also significantly associated with an increased risk for osteosarcoma (Savage et al. 2007), likely affecting interactions between ligands and IGF1R and leading to its increased activity. In addition, a multistage genomewide association study of the incidence of metastasis at diagnosis in 935 osteosarcoma patients identified a SNP rs7034162 in the nuclear factor 1 B-type (NFIB) gene that was significantly associated with metastasis in European, African and Brazilian patients (Mirabello et al. 2015). This study therefore identified NFIB, which encodes a transcription factor that regulates IGFBP5 expression in human osteoblasts (Perez-Casellas et al. 2009), as an osteosarcoma metastasis susceptibility gene. Interestingly, IGFBP5, the most abundant IGFBP stored in bone, inhibits tumor growth and metastasis of human osteosarcoma cells (Su et al. 2011, Luther et al. 2013).

The IGF1R pathway is a major autocrine loop that plays a key role in the pathogenesis and malignant behavior of Ewing sarcoma (Scotlandi et al. 1996, 1998, 2002, 2005, Scotlandi \& Picci 2008). EWS-FLI1, a fusion gene and genetic hallmark of Ewing sarcoma, was found to have transforming properties only in the presence of IGF1R (Toretsky et al. 1997), and more recently, this fusion product was found to directly affect IGF1R signaling by either downregulating IGFBP3 (Prieur et al. 2004) or increasing IGF1 promoter activation (Herrero-Martin et al. 2009, Amaral et al. 2015). Robust upregulation of IGF1 was also described in mesenchymal progenitor cells transformed by EWS-FLI1 (Riggi et al. 2005).

Data showing that a PAX3/7-FOXOA1 fusion protein, which is a genetic hallmark of alveolar rhabdomyosarcoma, activates the IGF1R gene promoter and increases expression of IGF1R are compelling (Ayalon et al. 2001). In addition, high levels of IGF2 in rhabdomyosarcoma were determined in previous studies describing loss of imprinting (Zhan et al. 1994, Wang et al. 1998), and IGF2 was found to cooperate with PAX3-FKHR in tumor oncogenesis (Wang et al. 1998, de Souza et al. 2012). Patients with stage III rhabdomyosarcoma can be categorized into patients who will proceed either poorly or well by considering high or low levels of Akt phosphorylation (i.e., higher or lower tonic IGF1R signaling (Crist et al. 2001, Petricoin et al. 2007)). As such, these findings further support the importance of IGF1R as a potential therapeutic modality in alveolar rhabdomyosarcoma.

Similarly, IGF1R has been found to be highly expressed in desmoplastic small cell tumors due to a direct activation of the IGF1R promoter by EWS-WT1, a genetic hallmark of this tumor. Interestingly, a truncated version of the fusion protein EWS-WT1 that has alternative mechanisms of action still stimulated IGF1R expression such that the receptor upregulation remained a consistent consequence of the genetic aberration in the fusion protein (Karnieli et al. 1996, Werner et al. 2007). In synovial sarcoma, elevated expression of IGF2 is induced by synovial sarcoma oncoprotein SYTSSX and appears to be required for tumor formation in vivo (Sun et al. 2006).

High expression of IGF2 was also observed in gastrointestinal stromal tumor (GIST) (Steigen et al. 2009). In addition, approximately 7\% of GISTs without tyrosine-protein kinase KIT or platelet-derived growth factor receptor alpha (PDGFRA) mutations were found to express IGF1R in excess of that seen in KIT or PDGFRA mutant GIST, and cell death was observed after treating these cell lines with IGF1R inhibitors (Agaram et al. 2008, Tarn et al. 2008).

The utility of IGF1R inhibitors (monoclonal antibodies and small-molecule tyrosine kinase inhibitors) was demonstrated in preclinical models against Ewing sarcoma, rhabdomyosarcoma, osteosarcoma, synovial sarcoma cells and desmoplastic round cell tumor, and these inhibitors were convincingly shown to block cancer cell proliferation, survival and anchorage-independent growth in vitro; to block tumorigenesis, tumor invasion and metastasis and to sensitize cancer cells to chemotherapy and radiotherapy (Kalebic et al. 1994, Scotlandi et al. 1998, 2005, Benini et al. 2001, Martins et al. 2006, Manara et al . 2007, Kolb \& Gorlick 2009).

Together, these findings strongly support the concept of pursuing IGF1R as a target for therapeutic intervention in these sarcomas.

\section{Results from clinical trials}

Numerous therapeutic agents targeting the IGF1R pathway have been developed. These agents include monoclonal 
antibodies (mAb) that specifically inhibit IGF1R (dalotuzumab, figitumumab, cixutumumab, ganitumab, R1507 and AVE1642); several IGF1R/IR tyrosine kinase inhibitors (TKIs), including a dual inhibitor of IGF1R and IR OSI-906 (linsitinib) (Mulvihill et al. 2009) and, more recently, monoclonal antibodies against IGF1 and IGF2 (MEDI-573 and BI 836845) (Gao et al. 2011, Friedbichler et al. 2014).

Different anti-IGF1R mAbs have been tested in early clinical trials involving patients with carcinomas and sarcomas. In sharp contrast with the effects of IGF1R inhibitor monotherapy in a subset of patients with sarcoma, largely unimpressive or even pessimistic results were obtained from studies of carcinoma (Qu et al. 2017). Table 1 summarizes the main clinical results obtained from sarcoma studies.
Initial clinical trials in patients with advanced, treatment-refractory sarcoma treated with IGF1R mAbs provided some positive indications (Haluska et al. 2007, Tolcher et al. 2009, Kurzrock et al. 2010) and led to larger trials (for a review, refer to Iams \& Lovly 2015). The most remarkable responses were obtained from studies describing Ewing sarcoma, in which a subset of patients showed a unique dependence on IGF1R signaling. To summarize, a complete response (CR) was achieved by a few patients with Ewing sarcoma, a partial response (PR) was achieved by $2-12 \%$ of patients, and disease stabilization rates ranged from $16 \%$ to $40 \%$ (Olmos et al. 2010, Juergens et al. 2011, Pappo et al. 2011, Tap et al. 2012). Much less impressive responses were observed in patients with recurrent or refractory rhabdomyosarcoma, synovial sarcoma and osteosarcoma (Pappo et al. 2014,

Table 1 Most important clinical studies involving anti-IGF1R agents in sarcomas.

Drug
R1507

Figitumumab (CP-751,871)

Figitumumab (CP-751,871)

Ganitumab

Cixutumumab (IMC-A12)

R1507

R1507

Robatumumab

Cixutumumab

(IMC-A12) + temsirolimus

Figitumumab

(CP-751,871) + everolimus

Cixutumumab

(IMC-A12) + temsirolimus

$\frac{\text { Phase }}{\mathrm{I}}$

Tumor types

9 pts with multiple Sarcoma subtypes; 9 pts with Ewing sarcoma

I 13 pts with multiple sarcoma subtypes; 16 pts with Ewing sarcoma

I $\quad 16$ pts with Ewing sarcoma; 11 with osteosarcoma; 4 with other sarcomas

106 pts with Ewing sarcoma 16 pts with Ewing sarcoma; 11 with osteosarcoma; 4 with other sarcomas

II $\quad 106$ pts with Ewing sarcoma

II 22 pts with Ewing sarcoma 16 with desmoplastic small round cell tumors

II $\quad 115$ pts with Ewing sarcoma

II 38 pts with osteosarcoma 36 pts with rhabdomyosarcoma 23 pts with synovial sarcoma 66 pts with other sarcomas

II 144 pts with Osteosarcoma or Ewing sarcoma metastasis

17 pts with Ewing's sarcoma 3 pts with desmoplastic small round cell tumors

I 19 pts with multiple Sarcoma subtypes

II 388 pts with bone and soft tissue sarcomas (61 pts with Ewing sarcoma)

Cixutumumab + doxorubicin I Pts with multiple soft tissue sarcoma subtypes

\section{Disease control \\ Ewing sarcoma: 2 PR; 2 SD \\ Leiomiosarcoma: $1 \mathrm{SD}$ \\ Synovial sarcoma: 1 SD \\ Fibrosarcoma: 1SD}

Ewing sarcoma: 1 CR; 1 PR; 6 SD Olmos et al. (2010)

15 PR; 25 SD

Ewing sarcoma: 1 PR; 8 SD

DSRCT: 1 PR; 13 SD

$1 \mathrm{CR} ; 10 \mathrm{PR} ; 18 \mathrm{SD}$

Osteosarcoma: 2 PR; 10 SD

Rhabdomyosarcoma: 1PR; 6 SD

Synovial Sarcoma: 4 SD

Other: 1 PR; 22 SD

Osteosarcoma: 3/60 CR or PR

Ewing sarcoma: 6/84 PR; 23/84

SD

Ewing sarcoma: 2 CR; 5 PR

DSRCT: 1 PR, 1 SD

Solitary fibrous tumor: $1 \mathrm{PR}$;

various: $14 \mathrm{DS}$

No CR

Ewing sarcoma: 4/27 PR

Osteosarcoma: 3/24 PR

Chondrosarcoma: 1/17

Solitary fibrous tumor: $1 / 8$

Various: 5/26 PR

$14 / 26$ SD
Juergens et al. (2011)

\section{References \\ Kurzrock et al. (2010)}

Tap et al. (2012)

Schoffski et al. (2013)

Pappo et al. (2011)

Pappo et al. (2014)

Anderson et al. (2016)

Naing et al. (2012)

Quek et al. (2011)

Schwartz et al. (2013)

Chugh et al. (2015)

$\mathrm{CR}$, complete response; PR, partial response; pts, patients; SD, stable disease. 
Anderson et al. 2016). In osteosarcoma, the lack of responses may have been due to the redundancy of autocrine loops that characterize this tumor (Benini et al. 1999), which likely prevented any efficacy of inhibitors specifically targeting single pathways. Of note, some evidence of efficacy was observed in osteosarcoma when multikinase inhibitor sorafenib was used (Grignani et al. 2015) in combination with everolimus, an mTOR inhibitor.

The combination of mTOR and IGF1R inhibition has been tested in patients with several types of advanced sarcomas and has occasionally yielded responses or prolonged disease stability in patients with metastatic solitary fibrous tumor; Ewing sarcoma; high-grade spindle cell sarcoma; osteosarcoma and, among soft tissue sarcoma, leiomyosarcoma (Quek et al. 2011, Naing et al. 2012, Schoffski et al. 2013). Considering the role of IGF1R in mediating resistance to chemotherapy, combinations of anti-IGF1R antibodies with cytotoxic agents, such as docetaxel, gemcitabine, erlotinib and doxorubicin, have also been tested (Macaulay et al. 2013, Chugh et al. 2015) and have yielded durable responses in a few patients with leiomyosarcoma. Toxicities observed were of a similar character and severity as those reported for each single agent, confirming the lack of serious safety concerns for agents targeting IGF1R even when used in combination. Moreover, the most common side effects, hyperglycemia and hyperlipidemia, are mostly tolerable and manageable. Combining anti-IGF1R mAbs with metformin, an antidiabetic drug with anticancer efficacy (Martin \& Marais 2012), may be a good choice to control hyperglycemia.

The major problems of IGF1R inhibition are not side effects but, rather, the rapid development of resistance with short-lived, clinical responses. Resistance to agents specifically targeting IGF1R is likely intrinsically associated with the complex, redundant interactions that characterize the IGF system. Garofalo and coworkers (Garofalo et al. 2011, 2012) and Beltran and coworkers (Beltran et al. 2011) proposed a compensatory signaling mediated by IGF2 through the IR that was not downregulated by anti-IGF1R antibodies. Alterations in downstream pathways, such as PI3K/AKT axis or RAS/ MAPK, modulation in IGFBPs expression or activation of alternative signaling have also been considered as potential mechanisms associated with resistance to anti-IGF1R agents (Cao et al. 2008, Haluska et al. 2008, Huang et al. 2010, Kang et al. 2014). Overexpression of epidermal growth factor receptor (EGFR) signaling was particularly suggested in adaptive resistance to IGF1R inhibition and vice versa (for a review see Jones et al.
2006), supporting the rationale for combining IGF1R and EGFR inhibitors, even in sarcomas. Particularly, the study performed by Huang et al. demonstrated the synergistic or additive effects given by the IGF1R/EGFR combined treatment in rhabdomyosarcoma cells (Huang et al. 2009). However, clinical trials have been disappointing. A phase I study in patients with solid tumors, including sarcomas, indicated that the human anti-IGF1R antibody AVE1642 was tolerable when combined with gemcitabine and erlotinib and achieved durable disease control in $44 \%$ of patients (Macaulay et al. 2013). However, a randomized phase 2 trial of erlotinib with or without the anti-IGF1R mAb R1507 failed to show difference in non-small-cell lung cancer and adding the dual IGF1R/IR linsitinib to erlotinib resulted in inferior outcomes compared with erlotinib alone (Leighl et al. 2017). Negative results were also obtained for colorectal cancer (Van Cutsem et al. 2014) and pancreatic cancer (Philip et al. 2014).

The appreciation of IR-mediated signaling as a potential mechanism of resistance to agents specifically directed against IGF1R has led to studies testing linsitinib, which simultaneously inhibits IGF1R and IR (Mulvihill et al. 2009), as well as antibodies directed against the IGF1 and IGF2 ligands (Gao et al. 2011) in patients with advanced solid tumors. Linsitinib has been evaluated as a single agent (Fassnacht et al. 2015, Jones et al. 2015, Puzanov et al. 2015) or, more recently, in combinations with paclitaxel or erlotinib in patients with metastatic carcinomas (Bendell et al. 2015, Ciuleanu et al. 2017, Leighl et al. 2017). Only very limited effects were reported. No data are available for sarcomas, although recent preclinical studies have indicated combined inhibition of IR and KIT as a potential therapeutic strategy in imatinibresistant GISTs (Chen et al. 2017).

MEDI-573 has also been tested in patients with advanced, heavily pretreated solid tumors, and these patients exhibited a disease stabilization rate of 30\% with no observed PRs or CRs (Haluska et al. 2014). A second phase I study of a Japanese population confirmed that MEDI-573 was well tolerated at the doses investigated but with limited efficacy (Iguchi et al. 2015).

Overall, clinical trials indicated that some treatment combinations induce disease stabilization in $20-40 \%$ of patients and clinical responses in a small percentage of patients with sarcoma, especially Ewing sarcoma.

Most studies noted the need of predictive biomarkers for identifying patients who would likely respond to this therapeutic strategy. To date, tumor expression of IGF1R (Schwartz et al. 2013) and its pathway components (Naing et al. 2011), serum IGF levels (Juergens et al. 2011, 
Pappo et al. 2011, Macaulay et al. 2013), assessment of alternate pathway activation and attempts at identifying specific molecular signatures associated with IGF1R pathway dependence have been analyzed with varying levels of success. Exclusive nuclear localization of IGF1R was associated with responses to various IGF1R Abs in patients with sarcoma, suggesting that IGF1R nuclear translocation could also be a biomarker of IGF pathway activation (Asmane et al. 2012). However, despite these findings, the interpretation of the heterogeneous responses in terms of efficacy and tolerability to therapies targeting IGF1R inhibitors is still far from being fully elucidated.

\section{Critical issues}

1. Scheduling and identification of predictive biomarkers remain to be resolved.

2. The sample size of clinical studies was too small. Phase 3 clinical trials were only a small proportion of the enrolled studies, and the overall population was not large enough to obtain relevant data.

3. An oversimplified vision of IGF signaling has very likely limited a full appreciation of the pathway, leading to a dismal scenario for the development of therapeutic agents in cancer.

\section{New perspectives}

1. Several lines of evidence provide a rationale for combining IGF signaling inhibitors and immune therapies. The contribution of the IGF axis in regulating immune function was first highlighted in a series of studies reporting that downregulating IGF1 or IGF1R enhanced the immunogenicity of glioblastoma models in rats (Resnicoff et al. 1994) as well as in a small clinical study on astrocytoma (Andrews et al. 2001). IGF1 has also been implicated in the expression of immunosuppressive cytokines, including interleukin-10 (Kooijman \& Coppens 2004), and the induction of the M2 macrophage phenotype (Barrett et al. 2015). A defect in IGF1/Akt signaling has been associated with a decreased capacity to induce the M2 state and an increased responsiveness to interferon gamma (IFN $\gamma$ ). This observation may be particularly relevant for osteosarcoma, in which tumor-associated macrophages (TAMs) were found to correlate with reduced metastasis and improved survival (Buddingh et al. 2011). Liposome-encapsulated muramyl tripeptide (L-MTP-PE), which enhances the potential antitumor activity of macrophages, has been introduced in the treatment of osteosarcoma patients (Meyers \& Chou 2014), and IL-10-polarized M2-like macrophages were able to reduce osteosarcoma cell growth in the presence of the anti-EGFR cetuximab in a mechanism involving antibody-dependent tumor cell phagocytosis (Pahl et al. 2014). In addition, inhibition of IGF1R promotes the expansion of activated human NK cells, which maintain antitumor responses against Ewing sarcoma (Jamitzky et al. 2015), indicating that combining adoptive NK cell transfer with IGF1R targeting may be an efficient strategy to eliminate minimal residual disease after conventional therapy.

2. Future clinical trial should select patients by specific biomarkers to increase efficacy. IGF1R antibodies were well tolerated in some trials, whereas, in others, they caused more severe side effects. The diverse effects and tolerance of IGF1R mAbs in different trials refer to many possible mechanisms, most of which were unclear. Understanding the mechanisms of these mAbs requires a better evaluation of the crosstalk between IGF1R and other signaling components (LamhamediCherradi et al. 2016) as well as consideration of players that have thus far been poorly considered in terms of IGF system regulation. These players may include the following:

a. Evaluation of IGF2BP family members. Correlative and functional studies have extensively described the elevated expression of IGF2BPs in human cancer but not in adult normal tissues, indicating an oncogenic role in different tumor types, including leukemia, carcinoma and bone and soft tissue tumors. In particular, high IGF2BP3 expression was reported in leiomyosarcoma (Cornejo et al. 2012), osteosarcoma (Do et al. 2008), chondrosarcoma (Shooshtarizadeh et al. 2016) and Ewing sarcoma (Mancarella et al. 2016). Due to its ability to sustain IGF2 expression with a consequent activation of IGF1R signaling pathway, IGF2BP3 may represent an intriguing biomarker to predict the therapeutic response to IGF1R inhibition. Accordingly, in vitro and in vivo evidence showed that sensitivity to the dual inhibitor linsitinib is higher in cancer cells overexpressing IGF2BP3 than in cells with low IGF2BP3 expression (Panebianco et al. 2017). In addition, IGF2BPs are envisioned as potential novel therapeutic targets, but so far, limited data are available regarding the direct inhibition of these proteins. In vitro evidence showed that treatment 
with an isocorydine derivative (d-ICD) inhibited IGF2BP3 expression and reduced the growth of hepatocellular carcinoma cells (Li et al. 2015). Beyond the possibility to directly block IGF2BP3 expression, the role of IGF3BP3 as a vaccine target was postulated. The study from Tomita and coworkers indicated that immunogenic peptides derived from IGF2BP3 can induce tumor-reactive and human leukocyte antigen (HLA)-A2 ( $\left.{ }^{*} 02: 01\right)$ restricted cytotoxic $\mathrm{T}$ lymphocytes (CTL) in lung cancer patients (Tomita et al. 2011), thus opening potential novel therapeutic avenues.

b. Evaluation of the metalloprotease PAPP-A. For tumors expressing high levels of PAPP-A, benefits of inhibiting its proteolytic activity have been described. In Mikkelsen et al. (2014) developed an inhibitory monoclonal antibody targeting a unique substrate-binding exosite of PAPP-A (mAb-PA). This antibody was shown to inhibit the proteolytic cleavage of IGFBP4, which blocked the intracellular signaling of IGF1R in vitro and in vivo (Mikkelsen et al. 2014). Afterwards, the efficacy of the mAb-PA was tested in primary patient ovarian xenografts showing that the efficacy of mAb-PA was strongly dependent on PAPP-A expression levels. Addition of mAb-PA to standard chemotherapy improved tumor regression (Becker et al. 2015). A very interesting aspect of this therapeutic approach is that the mAb-PA reduces the bioavailability of IGF1 and IGF2 but not of insulin, sparing any side effects due to metabolic dysregulation. PAPP-A has been described to be overexpressed in Ewing sarcoma, and TCR transgenic $\mathrm{T}$ cells directed against PAPP-A were found to reduce tumor growth in mice (Kirschner et al. 2017), thus providing novel possibilities in therapeutic approaches. Considering that even minor modifications in the balance of active and inhibited PAPP-A may have a large effect on the local or systemic generation of bioactive IGF1, more detailed studies on how the expression of PAPP-A and its regulators stanniocalcin 1 and 2 (STC1 and STC2) are controlled are strongly encouraged. STCs are involved in diverse physiological processes, including osteoblast differentiation, adipogenesis and chondrogenesis, indicating a possible diverse, more complex role in sarcomas than those in carcinomas. Deeper investigation of these factors, together with IGFBPs in sarcomas, may help in elucidating the differences observed in clinical trials. c. Evaluation of DDRs. DDR1 was reported to act as an oncogene in different tumor types. However, in mesenchymal tumors, the functions of these receptors may be more complex, considering the role that DDRs play in regulating the interactions of mesenchymal cells with collagens and the processes of neural, osteogenic, chondrogenic and myoblast differentiation (Valiathan et al. 2012). A complex functional crosstalk involving IGF1R, IRA, DDR1 and other important signaling molecules like G protein-coupled receptors (GPCRs) has been described to affect gene expression and biological effects in response to IGF1 or IGF2 (Malaguarnera et al. 2015, Avino et al. 2016, Mata et al. 2016, Vella et al. 2017). This multifaceted signaling network has been poorly considered in both the search of predictive biomarkers and the design of new therapeutic strategies in cancers with a dysregulated IGF system; however, a better understanding of these interactions may be clearly relevant. A recently developed compound $7 \mathrm{rh}$ is a selective and orally available specific inhibitor of DDR1 enzymatic activity and was found to potently inhibit proliferation, migration and tumorigenicity of cancer cells expressing high levels of DDR1 (Gao et al. 2013) and to improve the chemoresponse when combined with paclitaxel (Aguilera et al. 2017). Therefore, based on the biological affinity between the receptors, combined inhibition of IGF1R or IRA and DDR1 may be considered and investigated as a potential therapeutic strategy, especially in the treatment of sarcomas.

\section{Concluding remarks}

The IGF system is clearly involved in regulating tumor growth and, even more importantly, in developing resistance to conventional and targeted drugs. Unfortunately, clinical trials have been dismal, and the field has been largely abandoned. However, an exciting new area of research could help us develop new diagnoses and novel therapeutic approaches. The IGF system is complex, and a more profound level of understanding is required to achieve full exploitation of the therapeutic potentialities of the system. Therefore, clinical and basic researchers should continue to work together to provide new treatments for sarcoma patients. 


\section{Declaration of interest}

The authors declare that there is no conflict of interest that could be perceived as prejudicing the impartiality of this review.

\section{Funding}

This work was supported by the Italian Association for Cancer Research (IG2016_18451 to K S) and by the Istituto Ortopedico Rizzoli (5xmille contributions to the Rizzoli Institute). Caterina Mancarella was awarded the 'Guglielmina Lucatello e Gino Mazzega' fellowship granted by Fondazione Italiana per la Ricerca sul Cancro-FIRC (FIRC project code: 17984), and she was partially supported by the Guido Berlucchi Foundation.

\section{Acknowledgements}

The authors thank Cristina Ghinelli for figure editing.

\section{References}

Agaram NP, Laquaglia MP, Ustun B, Guo T, Wong GC, Socci ND, Maki RG, DeMatteo RP, Besmer P \& Antonescu CR 2008 Molecular characterization of pediatric gastrointestinal stromal tumors. Clinical Cancer Research 14 3204-3215. (https://doi.org/10.1158/1078-0432. CCR-07-1984)

Aguilera KY, Huang H, Du W, Hagopian MM, Wang Z, Hinz S, Hwang TH, Wang H, Fleming JB, Castrillon DH, et al. 2017 Inhibition of discoidin domain receptor 1 reduces collagen-mediated tumorigenicity in pancreatic ductal adenocarcinoma. Molecular Cancer Therapeutics 16 2473-2485. (https://doi.org/10.1158/15357163.MCT-16-0834)

Al-Kharobi H, El-Gendy R, Devine DA \& Beattie J 2014 The role of the insulinlike growth factor (IGF) axis in osteogenic and odontogenic differentiation. Cellular and Molecular Life Sciences 71 1469-1476. (https://doi.org/10.1007/s00018-013-1508-9)

Amaral AT, Garofalo C, Frapolli R, Manara MC, Mancarella C, Uboldi S, Di Giandomenico S, Ordonez JL, Sevillano V, Malaguarnera R, et al. 2015 Trabectedin efficacy in Ewing sarcoma is greatly increased by combination with anti-IGF signaling agents. Clinical Cancer Research 21 1373-1382. (https://doi.org/10.1158/1078-0432.CCR-14-1688)

Anderson PM, Bielack SS, Gorlick RG, Skubitz K, Daw NC, Herzog CE, Monge OR, Lassaletta A, Boldrini E, Papai Z, et al. 2016 A phase II study of clinical activity of SCH 717454 (robatumumab) in patients with relapsed osteosarcoma and Ewing sarcoma. Pediatric Blood and Cancer 63 1761-1770. (https://doi.org/10.1002/pbc.26087)

Andrews DW, Resnicoff M, Flanders AE, Kenyon L, Curtis M, Merli G, Baserga R, Iliakis G \& Aiken RD 2001 Results of a pilot study involving the use of an antisense oligodeoxynucleotide directed against the insulin-like growth factor type I receptor in malignant astrocytomas. Journal of Clinical Oncology 19 2189-2200. (https://doi. org/10.1200/JCO.2001.19.8.2189)

Asmane I, Watkin E, Alberti L, Duc A, Marec-Berard P, Ray-Coquard I, Cassier P, Decouvelaere AV, Ranchere D, Kurtz JE, et al. 2012 Insulinlike growth factor type 1 receptor (IGF-1R) exclusive nuclear staining: a predictive biomarker for IGF-1R monoclonal antibody (Ab) therapy in sarcomas. European Journal of Cancer 48 3027-3035. (https://doi.org/10.1016/j.ejca.2012.05.009)

Avino S, De Marco P, Cirillo F, Santolla MF, De Francesco EM, Perri MG, Rigiracciolo D, Dolce V, Belfiore A, Maggiolini M, et al. 2016 Stimulatory actions of IGF-I are mediated by IGF-IR cross-talk with GPER and DDR1 in mesothelioma and lung cancer cells. Oncotarget 7 52710-52728. (https://doi.org/10.18632/oncotarget.10348)
Ayalon D, Glaser T \& Werner H 2001 Transcriptional regulation of IGF-I receptor gene expression by the PAX3-FKHR oncoprotein. Growth Hormone and IGF Research 11 289-297. (https://doi.org/10.1054/ ghir.2001.0244)

Barrett JP, Minogue AM, Falvey A \& Lynch MA 2015 Involvement of IGF-1 and Akt in M1/M2 activation state in bone marrow-derived macrophages. Experimental Cell Research 335 258-268. (https://doi. org/10.1016/j.yexcr.2015.05.015)

Baxter RC 2000 Insulin-like growth factor (IGF)-binding proteins: interactions with IGFs and intrinsic bioactivities. American Journal of Physiology: Endocrinology and Metabolism 278 E967-E976. (https://doi. org/10.1152/ajpendo.2000.278.6.E967)

Becker MA, Haluska P Jr, Bale LK, Oxvig C \& Conover CA 2015 A novel neutralizing antibody targeting pregnancy-associated plasma protein-a inhibits ovarian cancer growth and ascites accumulation in patient mouse tumorgrafts. Molecular Cancer Therapeutics $\mathbf{1 4}$ 973-981. (https://doi.org/10.1158/1535-7163.MCT-14-0880)

Behjati S, Tarpey PS, Haase K, Ye H, Young MD, Alexandrov LB, Farndon SJ, Collord G, Wedge DC, Martincorena I, et al. 2017 Recurrent mutation of IGF signalling genes and distinct patterns of genomic rearrangement in osteosarcoma. Nature Communications 8 15936. (https://doi.org/10.1038/ncomms15936)

Belfiore A, Frasca F, Pandini G, Sciacca L \& Vigneri R 2009 Insulin receptor isoforms and insulin receptor/insulin-like growth factor receptor hybrids in physiology and disease. Endocrine Reviews 30 586-623. (https://doi.org/10.1210/er.2008-0047)

Beltran PJ, Chung YA, Moody G, Mitchell P, Cajulis E, Vonderfecht S, Kendall R, Radinsky R \& Calzone FJ 2011 Efficacy of ganitumab (AMG 479), alone and in combination with rapamycin, in Ewing's and osteogenic sarcoma models. Journal of Pharmacology and Experimental Therapeutics 337 644-654. (https://doi.org/10.1124/ jpet.110.178400)

Bendell JC, Jones SF, Hart L, Spigel DR, Lane CM, Earwood C, Infante JR, Barton J \& Burris HA 2015 A phase Ib study of linsitinib (OSI-906), a dual inhibitor of IGF-1R and IR tyrosine kinase, in combination with everolimus as treatment for patients with refractory metastatic colorectal cancer. Investigational New Drug 33 187-193. (https://doi. org/10.1007/s10637-014-0177-3)

Benini S, Baldini N, Manara MC, Chano T, Serra M, Rizzi S, Lollini PL, Picci P \& Scotlandi K 1999 Redundancy of autocrine loops in human osteosarcoma cells. International Journal of Cancer 80 581-588. (https://doi.org/10.1002/(SICI)1097-0215(19990209)80:4<581::AIDIJC16>3.0.CO;2-O)

Benini S, Manara MC, Baldini N, Cerisano V, Massimo S, Mercuri M, Lollini PL, Nanni P, Picci P \& Scotlandi K 2001 Inhibition of insulinlike growth factor I receptor increases the antitumor activity of doxorubicin and vincristine against Ewing's sarcoma cells. Clinical Cancer Research 7 1790-1797.

Brandhorst S, Choi IY, Wei M, Cheng CW, Sedrakyan S, Navarrete G, Dubeau L, Yap LP, Park R, Vinciguerra M, et al. 2015 A periodic diet that mimics fasting promotes multi-system regeneration, enhanced cognitive performance, and healthspan. Cell Metabolism 22 86-99. (https://doi.org/10.1016/j.cmet.2015.05.012)

Buddingh EP, Kuijjer ML, Duim RA, Burger H, Agelopoulos K, Myklebost O, Serra M, Mertens F, Hogendoorn PC, Lankester AC, et al. 2011 Tumor-infiltrating macrophages are associated with metastasis suppression in high-grade osteosarcoma: a rationale for treatment with macrophage activating agents. Clinical Cancer Research 17 2110-2119. (https://doi.org/10.1158/1078-0432.CCR-102047)

Butler AA, Yakar S, Gewolb IH, Karas M, Okubo Y \& LeRoith D 1998 Insulin-like growth factor-I receptor signal transduction: at the interface between physiology and cell biology. Comparative Biochemistry and Physiology Part B: Biochemistry and Molecular Biology 121 19-26. (https://doi.org/10.1016/S0305-0491(98)10106-2) 
Cannata D, Vijayakumar A, Fierz Y \& LeRoith D 2010 The GH/IGF-1 axis in growth and development: new insights derived from animal models. Advances in Pediatrics 57 331-351. (https://doi.org/10.1016/j yapd.2010.09.003)

Cao L, Yu Y, Darko I, Currier D, Mayeenuddin LH, Wan X, Khanna C \& Helman LJ 2008 Addiction to elevated insulin-like growth factor I receptor and initial modulation of the AKT pathway define the responsiveness of rhabdomyosarcoma to the targeting antibody. Cancer Research 68 8039-8048. (https://doi.org/10.1158/0008-5472. CAN-08-1712)

Cao Y, Roth M, Piperdi S, Montoya K, Sowers R, Rao P, Geller D, Houghton P, Kolb EA, Gill J, et al. 2014 Insulin-like growth factor 1 receptor and response to anti-IGF1R antibody therapy in osteosarcoma. PLOS ONE 9 e106249. (https://doi.org/10.1371/journal. pone.0106249)

Chan JM, Stampfer MJ, Giovannucci E, Gann PH, Ma J, Wilkinson P, Hennekens CH \& Pollak M 1998 Plasma insulin-like growth factor-I and prostate cancer risk: a prospective study. Science 279 563-566. (https://doi.org/10.1126/science.279.5350.563)

Chang Q, Li Y, White MF, Fletcher JA \& Xiao S 2002 Constitutive activation of insulin receptor substrate 1 is a frequent event in human tumors: therapeutic implications. Cancer Research 62 6035-6038.

Chen W, Kuang Y, Qiu HB, Cao Z, Tu Y, Sheng Q, Eilers G, He Q, Li HL, Zhu M, et al. 2017 Dual targeting of insulin receptor and KIT in imatinib-resistant gastrointestinal stromal tumors. Cancer Research $\mathbf{7 7}$ 5107-5117. (https://doi.org/10.1158/1538-7445.AM2017-5107)

Christiansen J, Kolte AM, Hansen T \& Nielsen FC 2009 IGF2 mRNAbinding protein 2: biological function and putative role in type 2 diabetes. Journal of Molecular Endocrinology 43 187-195. (https://doi. org/10.1677/JME-09-0016)

Chugh R, Griffith KA, Davis EJ, Thomas DG, Zavala JD, Metko G, Brockstein B, Undevia SD, Stadler WM \& Schuetze SM 2015 Doxorubicin plus the IGF-1R antibody cixutumumab in soft tissue sarcoma: a phase I study using the TITE-CRM model. Annals of Oncology 26 1459-1464. (https://doi.org/10.1093/annonc/mdv171)

Ciuleanu TE, Ahmed S, Kim JH, Mezger J, Park K, Thomas M, Chen J, Poondru S, VanTornout JM, Whitcomb D, et al. 2017 Randomised phase 2 study of maintenance linsitinib (OSI-906) in combination with erlotinib compared with placebo plus erlotinib after platinumbased chemotherapy in patients with advanced non-small cell lung cancer. British Journal of Cancer 117 757-766. (https://doi. org/10.1038/bjc.2017.226)

Clemmons DR 1998 Role of insulin-like growth factor binding proteins in controlling IGF actions. Molecular and Cellular Endocrinology 140 19-24. (https://doi.org/10.1016/S0303-7207(98)00024-0)

Conover CA 2012 Key questions and answers about pregnancyassociated plasma protein-A. Trends in Endocrinology and Metabolism 23 242-249. (https://doi.org/10.1016/j.tem.2012.02.008)

Cornejo K, Shi M \& Jiang Z 2012 Oncofetal protein IMP3: a useful diagnostic biomarker for leiomyosarcoma. Human Pathology $\mathbf{4 3}$ 1567-1572. (https://doi.org/10.1016/j.humpath.2011.12.020)

Crist WM, Anderson JR, Meza JL, Fryer C, Raney RB, Ruymann FB, Breneman J, Qualman SJ, Wiener E, Wharam M, et al. 2001 Intergroup rhabdomyosarcoma study-IV: results for patients with nonmetastatic disease. Journal of Clinical Oncology 19 3091-3102. (https://doi.org/10.1200/JCO.2001.19.12.3091)

Dauber A, Munoz-Calvo MT, Barrios V, Domene HM, Kloverpris S, SerraJuhe C, Desikan V, Pozo J, Muzumdar R, Martos-Moreno GA, et al. 2016 Mutations in pregnancy-associated plasma protein A2 cause short stature due to low IGF-I availability. EMBO Molecular Medicine 8 363-374. (https://doi.org/10.15252/emmm.201506106)

de Souza RR, Oliveira ID, Caran EM, Alves MT, Abib S \& Toledo SR 2012 Investigation of PAX3/7-FKHR fusion genes and IGF2 gene expression in rhabdomyosarcoma tumors. Growth Hormone and IGF Research 22 245-249. (https://doi.org/10.1016/j.ghir.2012.07.003)
Devi GR, De Souza AT, Byrd JC, Jirtle RL \& MacDonald RG 1999 Altered ligand binding by insulin-like growth factor II/mannose 6-phosphate receptors bearing missense mutations in human cancers. Cancer Research 59 4314-4319.

Do SI, Kim YW, Park HR \& Park YK 2008 Expression of insulin-like growth factor-II mRNA binding protein 3 (IMP3) in osteosarcoma. Oncology Research 17 269-272. (https://doi. org/10.3727/096504008786991639)

Duan Z, Choy E, Harmon D, Yang C, Ryu K, Schwab J, Mankin H \& Hornicek FJ 2009 Insulin-like growth factor-I receptor tyrosine kinase inhibitor cyclolignan picropodophyllin inhibits proliferation and induces apoptosis in multidrug resistant osteosarcoma cell lines. Molecular Cancer Therapeutics 8 2122-2130. (https://doi. org/10.1158/1535-7163.MCT-09-0115)

Egeblad M \& Werb Z 2002 New functions for the matrix metalloproteinases in cancer progression. Nature Reviews Cancer $\mathbf{2}$ 161-174. (https://doi.org/10.1038/nrc745)

Endogenous Hormones and Breast Cancer Collaborative Group, Key TJ, Appleby PN, Reeves GK \& Roddam AW 2010 Insulin-like growth factor 1 (IGF1), IGF binding protein 3 (IGFBP3), and breast cancer risk: pooled individual data analysis of 17 prospective studies. Lancet Oncology 11 530-542. (https://doi.org/10.1016/S1470-2045(10)700954)

Fassnacht M, Berruti A, Baudin E, Demeure MJ, Gilbert J, Haak H, Kroiss M, Quinn DI, Hesseltine E, Ronchi CL, et al. 2015 Linsitinib (OSI-906) versus placebo for patients with locally advanced or metastatic adrenocortical carcinoma: a double-blind, randomised, phase 3 study. Lancet Oncology 16 426-435. (https://doi.org/10.1016/ S1470-2045(15)70081-1)

Fawzy IO, Hamza MT, Hosny KA, Esmat G \& Abdelaziz AI 2016 Abrogating the interplay between IGF2BP1, 2 and 3 and IGF1R by let-7i arrests hepatocellular carcinoma growth. Growth Factors 34 42-50. (https://doi.org/10.3109/08977194.2016.1169532)

Frasca F, Pandini G, Sciacca L, Pezzino V, Squatrito S, Belfiore A \& Vigneri R 2008 The role of insulin receptors and IGF-I receptors in cancer and other diseases. Archives of Physiology and Biochemistry 114 23-37. (https://doi.org/10.1080/13813450801969715)

Friedbichler K, Hofmann MH, Kroez M, Ostermann E, Lamche HR, Koessl C, Borges E, Pollak MN, Adolf G \& Adam PJ 2014 Pharmacodynamic and antineoplastic activity of BI 836845, a fully human IGF ligand-neutralizing antibody, and mechanistic rationale for combination with rapamycin. Molecular Cancer Therapeutics $\mathbf{1 3}$ 399-409. (https://doi.org/10.1158/1535-7163.MCT-13-0598)

Gao J, Chesebrough JW, Cartlidge SA, Ricketts SA, Incognito L, Veldman-Jones M, Blakey DC, Tabrizi M, Jallal B, Trail PA, et al. 2011 Dual IGF-I/II-neutralizing antibody MEDI-573 potently inhibits IGF signaling and tumor growth. Cancer Research 71 1029-1040. (https:// doi.org/10.1158/0008-5472.CAN-10-2274)

Gao M, Duan L, Luo J, Zhang L, Lu X, Zhang Y, Zhang Z, Tu Z, Xu Y, Ren X,et al. 2013 Discovery and optimization of 3-(2-(pyrazolo[1,5-a] pyrimidin-6-yl)ethynyl)benzamides as novel selective and orally bioavailable discoidin domain receptor 1 (DDR1) inhibitors. Journal of Medicinal Chemistry 56 3281-3295. (https://doi.org/10.1021/ jm301824k)

Garofalo C, Manara MC, Nicoletti G, Marino MT, Lollini PL, Astolfi A, Pandini G, Lopez-Guerrero JA, Schaefer KL, Belfiore A, et al. 2011 Efficacy of and resistance to anti-IGF-1R therapies in Ewing's sarcoma is dependent on insulin receptor signaling. Oncogene 30 2730-2740. (https://doi.org/10.1038/onc.2010.640)

Garofalo C, Mancarella C, Grilli A, Manara MC, Astolfi A, Marino MT, Conte A, Sigismund S, Care A, Belfiore A, et al. 2012 Identification of common and distinctive mechanisms of resistance to different antiIGF-IR agents in Ewing's sarcoma. Molecular Endocrinology 26 1603-1616. (https://doi.org/10.1210/me.2012-1142)

Giorgetti S, Ballotti R, Kowalski-Chauvel A, Tartare S \& Van Obberghen E 1993 The insulin and insulin-like growth factor-I 
receptor substrate IRS-1 associates with and activates phosphatidylinositol 3-kinase in vitro. Journal of Biological Chemistry 268 7358-7364.

Granata R, Trovato L, Garbarino G, Taliano M, Ponti R, Sala G, Ghidoni R \& Ghigo E 2004 Dual effects of IGFBP-3 on endothelial cell apoptosis and survival: involvement of the sphingolipid signaling pathways. FASEB Journal 18 1456-1458.

Grey A, Chen Q, Xu X, Callon K \& Cornish J 2003 Parallel phosphatidylinositol-3 kinase and p42/44 mitogen-activated protein kinase signaling pathways subserve the mitogenic and antiapoptotic actions of insulin-like growth factor I in osteoblastic cells. Endocrinology 144 4886-4893. (https://doi.org/10.1210/ en.2003-0350)

Grignani G, Palmerini E, Ferraresi V, D’Ambrosio L, Bertulli R, Asaftei SD, Tamburini A, Pignochino Y, Sangiolo D, Marchesi E, et al. 2015 Sorafenib and everolimus for patients with unresectable highgrade osteosarcoma progressing after standard treatment: a nonrandomised phase 2 clinical trial. Lancet Oncology 16 98-107. (https://doi.org/10.1016/S1470-2045(14)71136-2)

Grimberg A \& Cohen P 2000 Role of insulin-like growth factors and their binding proteins in growth control and carcinogenesis. Journal of Cellular Physiology 183 1-9. (https://doi.org/10.1002/(SICI)10974652(200004)183:1<1::AID-JCP1>3.0.CO;2-J)

Hafner M, Landthaler M, Burger L, Khorshid M, Hausser J, Berninger P, Rothballer A, Ascano M Jr, Jungkamp AC, Munschauer M, et al. 2010 Transcriptome-wide identification of RNA-binding protein and microRNA target sites by PAR-CLIP. Cell 141 129-141. (https://doi. org/10.1016/j.cell.2010.03.009)

Haluska P, Carboni JM, TenEyck C, Attar RM, Hou X, Yu C, Sagar M, Wong TW, Gottardis MM \& Erlichman C 2008 HER receptor signaling confers resistance to the insulin-like growth factor-I receptor inhibitor, BMS-536924. Molecular Cancer Therapeutics 7 2589-2598. (https://doi.org/10.1158/1535-7163.MCT-08-0493)

Haluska P, Menefee M, Plimack ER, Rosenberg J, Northfelt D, LaVallee T, Shi L, Yu XQ, Burke P, Huang J, et al. 2014 Phase I dose-escalation study of MEDI-573, a bispecific, antiligand monoclonal antibody against IGFI and IGFII, in patients with advanced solid tumors. Clinical Cancer Research 20 4747-4757. (https://doi. org/10.1158/1078-0432.CCR-14-0114)

Haluska P, Shaw HM, Batzel GN, Yin D, Molina JR, Molife LR, Yap TA, Roberts ML, Sharma A, Gualberto A, et al. 2007 Phase I dose escalation study of the anti insulin-like growth factor-I receptor monoclonal antibody CP-751,871 in patients with refractory solid tumors. Clinical Cancer Research 13 5834-5840. (https://doi. org/10.1158/1078-0432.CCR-07-1118)

Han J, Jogie-Brahim S, Harada A \& Oh Y 2011 Insulin-like growth factorbinding protein-3 suppresses tumor growth via activation of caspasedependent apoptosis and cross-talk with NF-kappaB signaling. Cancer Letters 307 200-210. (https://doi.org/10.1016/j.canlet.2011.04.004)

Hemers E, Duval C, McCaig C, Handley M, Dockray GJ \& Varro A 2005 Insulin-like growth factor binding protein-5 is a target of matrix metalloproteinase-7: implications for epithelial-mesenchymal signaling. Cancer Research 65 7363-7369. (https://doi. org/10.1158/0008-5472.CAN-05-0157)

Herrero-Martin D, Osuna D, Ordonez JL, Sevillano V, Martins AS, Mackintosh C, Campos M, Madoz-Gurpide J, Otero-Motta AP, Caballero G, et al. 2009 Stable interference of EWS-FLI1 in an Ewing sarcoma cell line impairs IGF-1/IGF-1R signalling and reveals TOPK as a new target. British Journal of Cancer 101 80-90. (https://doi. org/10.1038/sj.bjc.6605104)

Huang F, Greer A, Hurlburt W, Han X, Hafezi R, Wittenberg GM, Reeves K, Chen J, Robinson D, Li A, et al. 2009 The mechanisms of differential sensitivity to an insulin-like growth factor-1 receptor inhibitor (BMS-536924) and rationale for combining with EGFR/ HER2 inhibitors. Cancer Research 69 161-170. (https://doi. org/10.1158/0008-5472.CAN-08-0835)
Huang F, Hurlburt W, Greer A, Reeves KA, Hillerman S, Chang H, Fargnoli J, Graf Finckenstein F, Gottardis MM \& Carboni JM 2010 Differential mechanisms of acquired resistance to insulin-like growth factor-I receptor antibody therapy or to a small-molecule inhibitor, BMS-754807, in a human rhabdomyosarcoma model. Cancer Research 70 7221-7231. (https://doi.org/10.1158/0008-5472.CAN-10-0391)

Iams WT \& Lovly CM 2015 Molecular pathways: clinical applications and future direction of insulin-like growth factor-1 receptor pathway blockade. Clinical Cancer Research 21 4270-4277. (https://doi. org/10.1158/1078-0432.CCR-14-2518)

Iguchi H, Nishina T, Nogami N, Kozuki T, Yamagiwa Y \& Yagawa K 2015 Phase I dose-escalation study evaluating safety, tolerability and pharmacokinetics of MEDI-573, a dual IGF-I/II neutralizing antibody, in Japanese patients with advanced solid tumours. Investigational New Drugs 33 194-200. (https://doi.org/10.1007/s10637-014-0170-x)

Jamitzky S, Krueger AC, Janneschuetz S, Piepke S, Kailayangiri S, Spurny C, Rossig C \& Altvater B 2015 Insulin-like growth factor-1 receptor (IGF-1R) inhibition promotes expansion of human NK cells which maintain their potent antitumor activity against Ewing sarcoma cells. Pediatric Blood and Cancer 62 1979-1985. (https://doi. org/10.1002/pbc.25619)

Jepsen MR, Kloverpris S, Mikkelsen JH, Pedersen JH, Fuchtbauer EM, Laursen LS \& Oxvig C 2015 Stanniocalcin-2 inhibits mammalian growth by proteolytic inhibition of the insulin-like growth factor axis. Journal of Biological Chemistry 290 3430-3439. (https://doi. org/10.1074/jbc.M114.611665)

Jones HE, Gee JM, Hutcheson IR, Knowlden JM, Barrow D \& Nicholson RI 2006 Growth factor receptor interplay and resistance in cancer. Endocrine-Related Cancer 13 (Supplement 1) S45-S51. (https://doi.org/10.1677/erc.1.01275)

Jones RL, Kim ES, Nava-Parada P, Alam S, Johnson FM, Stephens AW, Simantov R, Poondru S, Gedrich R, Lippman SM, et al. 2015 Phase I study of intermittent oral dosing of the insulin-like growth factor-1 and insulin receptors inhibitor OSI-906 in patients with advanced solid tumors. Clinical Cancer Research 21 693-700. (https://doi. org/10.1158/1078-0432.CCR-14-0265)

Juergens H, Daw NC, Geoerger B, Ferrari S, Villarroel M, Aerts I, Whelan J, Dirksen U, Hixon ML, Yin D, et al. 2011 Preliminary efficacy of the anti-insulin-like growth factor type 1 receptor antibody figitumumab in patients with refractory Ewing sarcoma. Journal of Clinical Oncology 29 4534-4540. (https://doi.org/10.1200/ JCO.2010.33.0670)

Kalebic T, Tsokos M \& Helman LJ 1994 In vivo treatment with antibody against IGF-1 receptor suppresses growth of human rhabdomyosarcoma and down-regulates p34cdc2. Cancer Research 54 5531-5534.

Kang Z, Yu Y, Zhu YJ, Davis S, Walker R, Meltzer PS, Helman LJ \& Cao L 2014 Downregulation of IGFBP2 is associated with resistance to IGF1R therapy in rhabdomyosarcoma. Oncogene 33 5697-5705. (https://doi.org/10.1038/onc.2013.509)

Kappel CC, Velez-Yanguas MC, Hirschfeld S \& Helman LJ 1994 Human osteosarcoma cell lines are dependent on insulin-like growth factor I for in vitro growth. Cancer Research 54 2803-2807.

Karnieli E, Werner H, Rauscher FJ 3rd, Benjamin LE \& LeRoith D 1996 The IGF-I receptor gene promoter is a molecular target for the Ewing's sarcoma-Wilms' tumor 1 fusion protein. Journal of Biological Chemistry 271 19304-19309. (https://doi.org/10.1074/ jbc.271.32.19304)

Kirschner A, Thiede M, Grunewald TG, Alba Rubio R, Richter GH, Kirchner T, Busch DH, Burdach S \& Thiel U 2017 Pappalysin-1 T cell receptor transgenic allo-restricted $\mathrm{T}$ cells kill Ewing sarcoma in vitro and in vivo. Oncoimmunology 6 e1273301. (https://doi.org/10.1080/2 162402X.2016.1273301)

Kloverpris S, Mikkelsen JH, Pedersen JH, Jepsen MR, Laursen LS, Petersen SV \& Oxvig C 2015 Stanniocalcin-1 potently inhibits the proteolytic activity of the metalloproteinase pregnancy-associated 
plasma protein-A. Journal of Biological Chemistry $29021915-21924$. (https://doi.org/10.1074/jbc.M115.650143)

Kolb EA \& Gorlick R 2009 Development of IGF-IR inhibitors in pediatric sarcomas. Current Oncology Report 11 307-313. (https://doi. org/10.1007/s11912-009-0043-1)

Kooijman R \& Coppens A 2004 Insulin-like growth factor-I stimulates IL-10 production in human T cells. Journal of Leukocyte Biology $\mathbf{7 6}$ 862-867. (https://doi.org/10.1189/jlb.0404248)

Kuijjer ML, Peterse EF, van den Akker BE, Briaire-de Bruijn IH, Serra M, Meza-Zepeda LA, Myklebost O, Hassan AB, Hogendoorn PC \& Cleton-Jansen AM 2013 IR/IGF1R signaling as potential target for treatment of high-grade osteosarcoma. BMC Cancer 13 245. (https:// doi.org/10.1186/1471-2407-13-245)

Kurzrock R, Patnaik A, Aisner J, Warren T, Leong S, Benjamin R, Eckhardt SG, Eid JE, Greig G, Habben K, et al. 2010 A phase I study of weekly R1507, a human monoclonal antibody insulin-like growth factor-I receptor antagonist, in patients with advanced solid tumors. Clinical Cancer Research 16 2458-2465. (https://doi. org/10.1158/1078-0432.CCR-09-3220)

Lamhamedi-Cherradi SE, Menegaz BA, Ramamoorthy V, Vishwamitra D, Wang Y, Maywald RL, Buford AS, Fokt I, Skora S, Wang J, et al. 2016 IGF-1R and mTOR blockade: novel resistance mechanisms and synergistic drug combinations for Ewing Sarcoma. Journal of the National Cancer Institute 108 djw182.

Leighl NB, Rizvi NA, de Lima LG Jr, Arpornwirat W, Rudin CM, Chiappori AA, Ahn MJ, Chow LQ, Bazhenova L, Dechaphunkul A, et al. 2017 Phase 2 study of erlotinib in combination with linsitinib (OSI-906) or placebo in chemotherapy-naive patients with nonsmall-cell lung cancer and activating epidermal growth factor receptor mutations. Clinical Lung Cancer 18 34.e32-42.e32.

Li M, Zhang L, Ge C, Chen L, Fang T, Li H, Tian H, Liu J, Chen T, Jiang G, et al. 2015 An isocorydine derivative (d-ICD) inhibits drug resistance by downregulating IGF2BP3 expression in hepatocellular carcinoma. Oncotarget 6 25149-25160. (https://doi.org/10.18632/ oncotarget.4438)

Luther GA, Lamplot J, Chen X, Rames R, Wagner ER, Liu X, Parekh A Huang E, Kim SH, Shen J, et al. 2013 IGFBP5 domains exert distinct inhibitory effects on the tumorigenicity and metastasis of human osteosarcoma. Cancer Letters 336 222-230. (https://doi.org/10.1016/j. canlet.2013.05.002)

Macaulay VM, Middleton MR, Protheroe AS, Tolcher A, Dieras V, Sessa C, Bahleda R, Blay JY, LoRusso P, Mery-Mignard D, et al. 2013 Phase I study of humanized monoclonal antibody AVE1642 directed against the type 1 insulin-like growth factor receptor (IGF-1R), administered in combination with anticancer therapies to patients with advanced solid tumors. Annals of Oncology 24 784-791. (https:// doi.org/10.1093/annonc/mds511)

MacEwen EG, Pastor J, Kutzke J, Tsan R, Kurzman ID, Thamm DH Wilson M \& Radinsky R 2004 IGF-1 receptor contributes to the malignant phenotype in human and canine osteosarcoma. Journal of Cellular Biochemistry 92 77-91. (https://doi.org/10.1002/jcb.20046)

Malaguarnera R, Nicolosi ML, Sacco A, Morcavallo A, Vella V, Voci C, Spatuzza M, Xu SQ, Iozzo RV, Vigneri R, et al. 2015 Novel cross talk between IGF-IR and DDR1 regulates IGF-IR trafficking, signaling and biological responses. Oncotarget 6 16084-16105. (https://doi. org/10.18632/oncotarget.3177)

Manara MC, Landuzzi L, Nanni P, Nicoletti G, Zambelli D, Lollini PL, Nanni C, Hofmann F, Garcia-Echeverria C, Picci P, et al. 2007 Preclinical in vivo study of new insulin-like growth factor-I receptor - specific inhibitor in Ewing's sarcoma. Clinical Cancer Research 13 1322-1330. (https://doi.org/10.1158/1078-0432.CCR-06-1518)

Mancarella C, Calzolari L, Ferrari S, Donati D, Picci P \& Scotlandi K 2016 Abstract 3201: insulin-like growth factor 2 (IGF-2) mRNA binding protein 3 predicts poor prognosis and promotes cell proliferation in Ewing sarcoma. Cancer Research 76 3201. (https:// doi.org/10.1158/1538-7445.AM2016-3201)
Manes S, Llorente M, Lacalle RA, Gomez-Mouton C, Kremer L, Mira E \& Martinez AC 1999 The matrix metalloproteinase-9 regulates the insulin-like growth factor-triggered autocrine response in DU-145 carcinoma cells. Journal of Biological Chemistry 274 6935-6945. (https://doi.org/10.1074/jbc.274.11.6935)

Martin-Kleiner I \& Gall Troselj K 2010 Mannose-6-phosphate/insulin-like growth factor 2 receptor (M6P/IGF2R) in carcinogenesis. Cancer Letters 289 11-22. (https://doi.org/10.1016/j.canlet.2009.06.036)

Martin M \& Marais R 2012 Metformin: a diabetes drug for cancer, or a cancer drug for diabetics? Journal of Clinical Oncology 30 2698-2700. (https://doi.org/10.1200/JCO.2012.42.1677)

Martins AS, Mackintosh C, Martin DH, Campos M, Hernandez T, Ordonez JL \& de Alava E 2006 Insulin-like growth factor I receptor pathway inhibition by ADW742, alone or in combination with imatinib, doxorubicin, or vincristine, is a novel therapeutic approach in Ewing tumor. Clinical Cancer Research 12 3532-3540. (https://doi. org/10.1158/1078-0432.CCR-05-1778)

Mata R, Palladino C, Nicolosi ML, Lo Presti AR, Malaguarnera R, Ragusa M, Sciortino D, Morrione A, Maggiolini M, Vella V, et al. 2016 IGF-I induces upregulation of DDR1 collagen receptor in breast cancer cells by suppressing MIR-199a-5p through the PI3K/AKT pathway. Oncotarget 7 7683-7700. (https://doi.org/10.18632/ oncotarget.6524)

Meyers PA \& Chou AJ 2014 Muramyl tripeptide-phosphatidyl ethanolamine encapsulated in liposomes (L-MTP-PE) in the treatment of osteosarcoma. Advances in Experimental Medicine and Biology 804 307-321.

Mikkelsen JH, Resch ZT, Kalra B, Savjani G, Kumar A, Conover CA \& Oxvig C 2014 Indirect targeting of IGF receptor signaling in vivo by substrate-selective inhibition of PAPP-A proteolytic activity. Oncotarget 5 1014-1025. (https://doi.org/10.18632/ oncotarget.1629)

Mirabello L, Koster R, Moriarity BS, Spector LG, Meltzer PS, Gary J, Machiela MJ, Pankratz N, Panagiotou OA, Largaespada D, et al. 2015 A genome-wide scan identifies variants in NFIB associated with metastasis in patients with osteosarcoma. Cancer Discovery 5 920-931. (https://doi.org/10.1158/2159-8290.CD-15-0125)

Mohan S \& Baylink DJ 2002 IGF-binding proteins are multifunctional and act via IGF-dependent and -independent mechanisms. Journal of Endocrinology 175 19-31. (https://doi.org/10.1677/joe.0.1750019)

Morcavallo A, Gaspari M, Pandini G, Palummo A, Cuda G, Larsen MR, Vigneri R \& Belfiore A 2011 Research resource: new and diverse substrates for the insulin receptor isoform a revealed by quantitative proteomics after stimulation with IGF-II or insulin. Molecular Endocrinology 25 1456-1468. (https://doi.org/10.1210/me.2010-0484)

Mulvihill MJ, Cooke A, Rosenfeld-Franklin M, Buck E, Foreman K, Landfair D, O'Connor M, Pirritt C, Sun Y, Yao Y, et al. 2009 Discovery of OSI-906: a selective and orally efficacious dual inhibitor of the IGF-1 receptor and insulin receptor. Future Medicinal Chemistry 1 1153-1171. (https://doi.org/10.4155/fmc.09.89)

Naing A, Kurzrock R, Burger A, Gupta S, Lei X, Busaidy N, Hong D, Chen HX, Doyle LA, Heilbrun LK, et al. 2011 Phase I trial of cixutumumab combined with temsirolimus in patients with advanced cancer. Clinical Cancer Research 17 6052-6060. (https://doi. org/10.1158/1078-0432.CCR-10-2979)

Naing A, LoRusso P, Fu S, Hong DS, Anderson P, Benjamin RS, Ludwig J, Chen HX, Doyle LA \& Kurzrock R 2012 Insulin growth factorreceptor (IGF-1R) antibody cixutumumab combined with the mTOR inhibitor temsirolimus in patients with refractory Ewing's sarcoma family tumors. Clinical Cancer Research 18 2625-2631. (https://doi. org/10.1158/1078-0432.CCR-12-0061)

Nielsen J, Christiansen J, Lykke-Andersen J, Johnsen AH, Wewer UM \& Nielsen FC 1999 A family of insulin-like growth factor II mRNAbinding proteins represses translation in late development. Molecular and Cellular Biology 19 1262-1270. (https://doi.org/10.1128/ MCB.19.2.1262) 
Olmos D, Postel-Vinay S, Molife LR, Okuno SH, Schuetze SM, Paccagnella ML, Batzel GN, Yin D, Pritchard-Jones K, Judson I, et al. 2010 Safety, pharmacokinetics, and preliminary activity of the antiIGF-1R antibody figitumumab (CP-751,871) in patients with sarcoma and Ewing's sarcoma: a phase 1 expansion cohort study. Lancet Oncology 11 129-135. (https://doi.org/10.1016/S14702045(09)70354-7)

Pahl JH, Kwappenberg KM, Varypataki EM, Santos SJ, Kuijjer ML, Mohamed S, Wijnen JT, van Tol MJ, Cleton-Jansen AM, Egeler RM, et al. 2014 Macrophages inhibit human osteosarcoma cell growth after activation with the bacterial cell wall derivative liposomal muramyl tripeptide in combination with interferon-gamma. Journal of Experimental and Clinical Cancer Research 33 27. (https://doi. org/10.1186/1756-9966-33-27)

Panebianco F, Kelly LM, Liu P, Zhong S, Dacic S, Wang X, Singhi AD, Dhir R, Chiosea SI, Kuan SF, et al. 2017 THADA fusion is a mechanism of IGF2BP3 activation and IGF1R signaling in thyroid cancer. PNAS 114 2307-2312. (https://doi.org/10.1073/ pnas.1614265114)

Pappo AS, Patel SR, Crowley J, Reinke DK, Kuenkele KP, Chawla SP, Toner GC, Maki RG, Meyers PA, Chugh R, et al. 2011 R1507, a monoclonal antibody to the insulin-like growth factor 1 receptor, in patients with recurrent or refractory Ewing sarcoma family of tumors: results of a phase II sarcoma alliance for research through collaboration study. Journal of Clinical Oncology 29 4541-4547. (https://doi.org/10.1200/JCO.2010.34.0000)

Pappo AS, Vassal G, Crowley JJ, Bolejack V, Hogendoorn PC, Chugh R, Ladanyi M, Grippo JF, Dall G, Staddon AP, et al. 2014 A phase 2 trial of R1507, a monoclonal antibody to the insulin-like growth factor-1 receptor (IGF-1R), in patients with recurrent or refractory rhabdomyosarcoma, osteosarcoma, synovial sarcoma, and other soft tissue sarcomas: results of a sarcoma alliance for research through collaboration study. Cancer 120 2448-2456. (https://doi.org/10.1002/ cncr.28728)

Perez-Casellas LA, Wang X, Howard KD, Rehage MW, Strong DD \& Linkhart TA 2009 Nuclear factor I transcription factors regulate IGF binding protein 5 gene transcription in human osteoblasts. Biochimica et Biophysica Acta 1789 78-87. (https://doi.org/10.1016/j. bbagrm.2008.08.013)

Petricoin EF 3rd, Espina V, Araujo RP, Midura B, Yeung C, Wan X, Eichler GS, Johann DJ Jr, Qualman S, Tsokos M, et al. 2007 Phosphoprotein pathway mapping: akt/mammalian target of rapamycin activation is negatively associated with childhood rhabdomyosarcoma survival. Cancer Research 67 3431-3440. (https:// doi.org/10.1158/0008-5472.CAN-06-1344)

Philip PA, Goldman B, Ramanathan RK, Lenz HJ, Lowy AM, Whitehead RP, Wakatsuki T, Iqbal S, Gaur R, Benedetti JK, et al. 2014 Dual blockade of epidermal growth factor receptor and insulin-like growth factor receptor-1 signaling in metastatic pancreatic cancer: phase Ib and randomized phase II trial of gemcitabine, erlotinib, and cixutumumab versus gemcitabine plus erlotinib (SWOG S0727). Cancer 120 2980-2985. (https://doi.org/10.1002/cncr.28744)

Prieur A, Tirode F, Cohen P \& Delattre O 2004 EWS/FLI-1 silencing and gene profiling of Ewing cells reveal downstream oncogenic pathways and a crucial role for repression of insulin-like growth factor binding protein 3. Molecular and Cellular Biology 24 7275-7283. (https://doi. org/10.1128/MCB.24.16.7275-7283.2004)

Puzanov I, Lindsay CR, Goff L, Sosman J, Gilbert J, Berlin J, Poondru S, Simantov R, Gedrich R, Stephens A, et al. 2015 A phase I study of continuous oral dosing of OSI-906, a dual inhibitor of insulin-like growth factor-1 and insulin receptors, in patients with advanced solid tumors. Clinical Cancer Research 21 701-711. (https://doi. org/10.1158/1078-0432.CCR-14-0303)

Qu X, Wu Z, Dong W, Zhang T, Wang L, Pang Z, Ma W \& Du J 2017 Update of IGF-1 receptor inhibitor (ganitumab, dalotuzumab, cixutumumab, teprotumumab and figitumumab) effects on cancer therapy. Oncotarget 8 29501-29518.

Quek R, Wang Q, Morgan JA, Shapiro GI, Butrynski JE, Ramaiya N, Huftalen T, Jederlinic N, Manola J, Wagner AJ, et al. 2011 Combination mTOR and IGF-1R inhibition: phase I trial of everolimus and figitumumab in patients with advanced sarcomas and other solid tumors. Clinical Cancer Research 17 871-879. (https:// doi.org/10.1158/1078-0432.CCR-10-2621)

Resnicoff M, Sell C, Rubini M, Coppola D, Ambrose D, Baserga R \& Rubin R 1994 Rat glioblastoma cells expressing an antisense RNA to the insulin-like growth factor-1 (IGF-1) receptor are nontumorigenic and induce regression of wild-type tumors. Cancer Research $\mathbf{5 4}$ 2218-2222.

Riggi N, Cironi L, Provero P, Suva ML, Kaloulis K, Garcia-Echeverria C, Hoffmann F, Trumpp A \& Stamenkovic I 2005 Development of Ewing's sarcoma from primary bone marrow-derived mesenchymal progenitor cells. Cancer Research 65 11459-11468. (https://doi. org/10.1158/0008-5472.CAN-05-1696)

Rinaldi S, Cleveland R, Norat T, Biessy C, Rohrmann S, Linseisen J, Boeing H, Pischon T, Panico S, Agnoli C, et al. 2010 Serum levels of IGF-I, IGFBP-3 and colorectal cancer risk: results from the EPIC cohort, plus a meta-analysis of prospective studies. International Journal of Cancer 126 1702-1715.

Samani AA \& Brodt P 2001 The receptor for the type I insulin-like growth factor and its ligands regulate multiple cellular functions that impact on metastasis. Surgical Oncology Clinics of North America 10 289-312, viii.

Samani AA, Yakar S, LeRoith D \& Brodt P 2007 The role of the IGF system in cancer growth and metastasis: overview and recent insights. Endocrine Reviews 28 20-47. (https://doi.org/10.1210/ er.2006-0001)

Savage SA, Woodson K, Walk E, Modi W, Liao J, Douglass C, Hoover RN, Chanock SJ \& National Osteosarcoma Etiology Study Group 2007 Analysis of genes critical for growth regulation identifies insulin-like growth factor 2 receptor variations with possible functional significance as risk factors for osteosarcoma. Cancer Epidemiology, Biomarkers and Prevention 16 1667-1674. (https://doi org/10.1158/1055-9965.EPI-07-0214)

Schmid C, Steiner T \& Froesch ER 1983 Preferential enhancement of myoblast differentiation by insulin-like growth factors (IGF I and IGF II) in primary cultures of chicken embryonic cells. FEBS Letters 161 117-121. (https://doi.org/10.1016/0014-5793(83)80742-X)

Schoffski P, Adkins D, Blay JY, Gil T, Elias AD, Rutkowski P, Pennock GK, Youssoufian H, Gelderblom H, Willey R, et al. 2013 An open-label, phase 2 study evaluating the efficacy and safety of the anti-IGF-1R antibody cixutumumab in patients with previously treated advanced or metastatic soft-tissue sarcoma or Ewing family of tumours. European Journal of Cancer 49 3219-3228. (https://doi.org/10.1016/j. ejca.2013.06.010)

Schwartz GK, Tap WD, Qin LX, Livingston MB, Undevia SD, Chmielowski B, Agulnik M, Schuetze SM, Reed DR, Okuno SH, et al. 2013 Cixutumumab and temsirolimus for patients with bone and soft-tissue sarcoma: a multicentre, open-label, phase 2 trial. Lancet Oncology 14 371-382. (https://doi.org/10.1016/S1470-2045(13)700494)

Scotlandi K, Avnet S, Benini S, Manara MC, Serra M, Cerisano V, Perdichizzi S, Lollini PL, De Giovanni C, Landuzzi L, et al. 2002 Expression of an IGF-I receptor dominant negative mutant induces apoptosis, inhibits tumorigenesis and enhances chemosensitivity in Ewing's sarcoma cells. International Journal of Cancer 101 11-16. (https://doi.org/10.1002/ijc.10537)

Scotlandi K, Benini S, Nanni P, Lollini PL, Nicoletti G, Landuzzi L, Serra M, Manara MC, Picci P \& Baldini N 1998 Blockage of insulinlike growth factor-I receptor inhibits the growth of Ewing's sarcoma in athymic mice. Cancer Research 58 4127-4131. 
Scotlandi K, Benini S, Sarti M, Serra M, Lollini PL, Maurici D, Picci P, Manara MC \& Baldini N 1996 Insulin-like growth factor I receptor-mediated circuit in Ewing's sarcoma/peripheral neuroectodermal tumor: a possible therapeutic target. Cancer Research 56 4570-4574.

Scotlandi K, Manara MC, Nicoletti G, Lollini PL, Lukas S, Benini S, Croci S, Perdichizzi S, Zambelli D, Serra M, et al. 2005 Antitumor activity of the insulin-like growth factor-I receptor kinase inhibitor NVP-AEW541 in musculoskeletal tumors. Cancer Research 65 3868-3876. (https://doi.org/10.1158/0008-5472.CAN-04-3192)

Scotlandi K \& Picci P 2008 Targeting insulin-like growth factor 1 receptor in sarcomas. Current Opinion in Oncology 20 419-427. (https://doi.org/10.1097/CCO.0b013e328302edab)

Sell C, Rubini M, Rubin R, Liu JP, Efstratiadis A \& Baserga R 1993 Simian virus 40 large tumor antigen is unable to transform mouse embryonic fibroblasts lacking type 1 insulin-like growth factor receptor. PNAS 90 11217-11221. (https://doi.org/10.1073/ pnas.90.23.11217)

Shevah O \& Laron Z 2007 Patients with congenital deficiency of IGF-I seem protected from the development of malignancies: a preliminary report. Growth Hormone and IGF Research 17 54-57. (https://doi.org/10.1016/j.ghir.2006.10.007)

Shooshtarizadeh T, Nazeri A, Zare-Mirzaie A \& Movahedinia S 2016 Expression of insulin-like growth factor II mRNA binding protein 3 (IMP3) in enchondroma and chondrosarcoma. Pathology, Research and Practice 212 335-339. (https://doi.org/10.1016/j.prp.2016.02.006)

Steigen SE, Schaeffer DF, West RB \& Nielsen TO 2009 Expression of insulin-like growth factor 2 in mesenchymal neoplasms. Modern Pathology 22 914-921. (https://doi.org/10.1038/modpathol.2009.48)

Su Y, Wagner ER, Luo Q, Huang J, Chen L, He BC, Zuo GW, Shi Q, Zhang BQ, Zhu G, et al. 2011 Insulin-like growth factor binding protein 5 suppresses tumor growth and metastasis of human osteosarcoma. Oncogene 30 3907-3917. (https://doi.org/10.1038/ onc.2011.97)

Sun Y, Gao D, Liu Y, Huang J, Lessnick S \& Tanaka S 2006 IGF2 is critical for tumorigenesis by synovial sarcoma oncoprotein SYT-SSX1. Oncogene 25 1042-1052. (https://doi.org/10.1038/sj.onc.1209143)

Taniguchi CM, Emanuelli B \& Kahn CR 2006 Critical nodes in signalling pathways: insights into insulin action. Nature Reviews Molecular Cell Biology 7 85-96. (https://doi.org/10.1038/nrm1837)

Tap WD, Demetri G, Barnette P, Desai J, Kavan P, Tozer R, Benedetto PW, Friberg G, Deng H, McCaffery I, et al. 2012 Phase II study of ganitumab, a fully human anti-type-1 insulin-like growth factor receptor antibody, in patients with metastatic Ewing family tumors or desmoplastic small round cell tumors. Journal of Clinical Oncology 30 1849-1856.

Tarn C, Rink L, Merkel E, Flieder D, Pathak H, Koumbi D, Testa JR, Eisenberg B, von Mehren M \& Godwin AK 2008 Insulin-like growth factor 1 receptor is a potential therapeutic target for gastrointestinal stromal tumors. PNAS 105 8387-8392. (https://doi.org/10.1073/ pnas.0803383105)

Tolcher AW, Sarantopoulos J, Patnaik A, Papadopoulos K, Lin CC, Rodon J, Murphy B, Roth B, McCaffery I, Gorski KS, et al. 2009 Phase I, pharmacokinetic, and pharmacodynamic study of AMG 479, a fully human monoclonal antibody to insulin-like growth factor receptor 1. Journal of Clinical Oncology 27 5800-5807. (https://doi. org/10.1200/JCO.2009.23.6745)

Tomita Y, Harao M, Senju S, Imai K, Hirata S, Irie A, Inoue M, Hayashida Y, Yoshimoto K, Shiraishi K, et al. 2011 Peptides derived from human insulin-like growth factor-II mRNA binding protein 3 can induce human leukocyte antigen-A2-restricted cytotoxic T lymphocytes reactive to cancer cells. Cancer Science 102 71-78. (https://doi.org/10.1111/j.1349-7006.2010.01780.x)

Toretsky JA, Kalebic T, Blakesley V, LeRoith D \& Helman LJ 1997 The insulin-like growth factor-I receptor is required for EWS/FLI-1 transformation of fibroblasts. Journal of Biological Chemistry $\mathbf{2 7 2}$ 30822-30827. (https://doi.org/10.1074/jbc.272.49.30822)

Ursini-Siegel J, Hardy WR, Zuo D, Lam SH, Sanguin-Gendreau V, Cardiff RD, Pawson T \& Muller WJ 2008 ShcA signalling is essential for tumour progression in mouse models of human breast cancer. EMBO Journal 27 910-920. (https://doi.org/10.1038/emboj.2008.22)

Valiathan RR, Marco M, Leitinger B, Kleer CG \& Fridman R 2012 Discoidin domain receptor tyrosine kinases: new players in cancer progression. Cancer and Metastasis Reviews 31 295-321. (https://doi. org/10.1007/s10555-012-9346-z)

Van Cutsem E, Eng C, Nowara E, Swieboda-Sadlej A, Tebbutt NC, Mitchell E, Davidenko I, Stephenson J, Elez E, Prenen H, et al. 2014 Randomized phase $\mathrm{Ib} / \mathrm{II}$ trial of rilotumumab or ganitumab with panitumumab versus panitumumab alone in patients with wild-type KRAS metastatic colorectal cancer. Clinical Cancer Research 20 4240-4250. (https://doi.org/10.1158/1078-0432.CCR-13-2752)

Vella V, Malaguarnera R, Nicolosi ML, Palladino C, Spoleti C, Massimino M, Vigneri P, Purrello M, Ragusa M, Morrione A, et al. 2017 Discoidin domain receptor 1 modulates insulin receptor signaling and biological responses in breast cancer cells. Oncotarget $\mathbf{8}$ 43248-43270.

Viereck V, Siggelkow H, Pannem R, Braulke T, Scharf JG \& Kubler B 2007 Alteration of the insulin-like growth factor axis during in vitro differentiation of the human osteosarcoma cell line HOS 58. Journal of Cellular Biochemistry 102 28-40. (https://doi.org/10.1002/ jcb.21274)

Wang W, Kumar P, Wang W, Epstein J, Helman L, Moore JV \& Kumar S 1998 Insulin-like growth factor II and PAX3-FKHR cooperate in the oncogenesis of rhabdomyosarcoma. Cancer Research 58 4426-4433.

Wei J, Shimazu J, Makinistoglu MP, Maurizi A, Kajimura D, Zong H, Takarada T, Lezaki T, Pessin JE, Hinoi E, et al. 2015 Glucose uptake and Runx2 synergize to orchestrate osteoblast differentiation and bone formation. Cell 161 1576-1591. (https://doi.org/10.1016/j. cell.2015.05.029)

Werner H, Idelman G, Rubinstein M, Pattee P, Nagalla SR \& Roberts CT Jr 2007 A novel EWS-WT1 gene fusion product in desmoplastic small round cell tumor is a potent transactivator of the insulin-like growth factor-I receptor (IGF-IR) gene. Cancer Letters 247 84-90. (https://doi. org/10.1016/j.canlet.2006.03.027)

Yang R, Piperdi S, Zhang Y, Zhu Z, Neophytou N, Hoang BH, Mason G, Geller D, Dorfman H, Meyers PA, et al. 2016 Transcriptional profiling identifies the signaling axes of IGF and transforming growth factor-b as involved in the pathogenesis of osteosarcoma. Clinical Orthopaedics and Related Research 474 178-189. (https://doi. org/10.1007/s11999-015-4578-1)

Zhan S, Shapiro DN \& Helman LJ 1994 Activation of an imprinted allele of the insulin-like growth factor II gene implicated in rhabdomyosarcoma. Journal of Clinical Investigation 94 445-448. (https://doi.org/10.1172/JCI117344)

Zhao H, Dupont J, Yakar S, Karas M \& LeRoith D 2004 PTEN inhibits cell proliferation and induces apoptosis by downregulating cell surface IGF-IR expression in prostate cancer cells. Oncogene $\mathbf{2 3}$ 786-794. (https://doi.org/10.1038/sj.onc.1207162)

Received in final form 19 December 2017 Accepted 22 December 2017 